\title{
SISTEMA DE TRANSPORTE COLETIVO POR ÔNIBUS NA CIDADE DE VITÓRIA DA CONQUISTA - BA: UMA ABORDAGEM SOBRE A MOBILIDADE URBANA
}

\section{ARTIGO ORIGINAL}

SILVA, Lettycia Pinheiro da ${ }^{1}$

DIAS, Anderson Caires Silva ${ }^{2}$

VARGAS, Carlos Eduardo Coqueiro ${ }^{3}$

SOUZA, Maiane Miranda da Silva ${ }^{4}$

SOUZA, Rômulo Miranda ${ }^{5}$

SOUZA, Aldair Marinho ${ }^{6}$

LIMA, Lívia Ramos $^{7}$

SILVA, Lettycia Pinheiro da. Et al. Sistema de transporte coletivo por ônibus na cidade de Vitória da Conquista - BA: uma abordagem sobre a mobilidade urbana. Revista Científica Multidisciplinar Núcleo do Conhecimento. Ano 05, Ed. 05, Vol. 09, pp. 147-178. Maio de 2020. ISSN: 2448-0959, Link de

\footnotetext{
${ }^{1}$ Pós-graduanda em Geotecnia e graduanda em Engenharia Civil.

2 Graduando em Engenharia Civil.

${ }^{3}$ Graduando em Engenharia Civil.

${ }^{4}$ Graduanda em Engenharia Civil.

${ }^{5}$ Graduando em Engenharia Civil.

${ }^{6}$ Mestrado profissional em andamento em Bioenergia. Especialização em Magistério Superior. Graduação em Licenciatura em Física. Graduação em Engenharia Civil.

${ }^{7}$ Especialização em Engenharia Rodoviária: Do Estudo De Viabilidade Ao Projeto Executivo. Graduação em Engenharia Civil. Graduação em Enfermagem.
} 
acesso: https://www.nucleodoconhecimento.com.br/engenharia-civil/transportecoletivo

\section{RESUMO}

Em se tratando da vida nas cidades, o sistema de transporte coletivo por ônibus representa uma importante ferramenta de mobilidade urbana, sendo parte fundamental do cotidiano dos cidadãos direita e indiretamente. Sendo esse sistema tão significativo para a configuração espacial, econômica, viária e da organização social de uma cidade, é imprescindível que este contemple todas as parcelas da população, e, para este fim, é necessário que o sistema siga as preconizações normativas e legislações vigentes no que se refere à acessibilidade. Este artigo tem como objetivo investigar os pontos de embarque e desembarque do sistema de transporte coletivo do município de Vitória da Conquista, por meio da análise de uma das 47 linhas operantes, verificando o cumprimento da norma de acessibilidade - NBR 9050/2015. Foi possível perceber que, apesar de ser parte essencial da mobilidade urbana, a acessibilidade muitas vezes não é um critério recebe a devida atenção.

Palavras-chave: Mobilidade urbana, acessibilidade, Sistema de Transporte Coletivo.

\section{INTRODUÇÃO}

\subsection{DELIMITAÇÃO DO TEMA E PROBLEMA DE PESQUISA}

A mobilidade urbana, que tem sido tema de discussões no atual cenário brasileiro, se configura como um dos principais fatores da orientação de crescimento e do desenvolvimento de uma cidade e, por consequência, da configuração espacial, da organização social, econômica e viária da mesma. Um dos grandes desafios que devem ser englobados pela mobilidade urbana é a inserção de parcelas consideráveis da população na vida nas cidades, promovendo, assim, a inclusão social à medida que proporciona acesso amplo e democrático ao espaço urbano (MURATA, 2015). 
Segundo Duarte, Sánchez e Libardi (2017), a maneira com a qual é vista a sociedade e sua formação depende diretamente dos meios de transporte que são utilizados. Os autores defendem também a ideia de que todos os seres humanos são pedestres e passam a estar em outra posição em determinados momentos, seja essa posição motorista ou usuário do sistema de transporte coletivo, sendo assim, a sociedade deveria ser moldada em função dos pedestres e em seguida dos outros modais de transporte.

De fundamental relevância para o desenvolvimento e organização das cidades é o sistema de Transporte Coletivo Urbano - TCU - ele apresenta grande importância no cenário das cidades visto que é uma alternativa democrática e social que é representada por um modo de transporte motorizado, seguro e cômodo, que é, em teoria, acessível às pessoas de baixa renda, assim como àquelas com necessidades especiais ou mobilidade reduzida.

A realidade do TCU em cidades de médio porte no Brasil é totalmente oposta daquilo que é previsto em normas e leis vigentes. A gestão e o planejamento são feitos de forma ineficaz e a operação deixa a desejar, e detalhes considerados simples, como condições dos veículos, das vias e dos pontos de parada, são negligenciados, o que implica de forma negativa na economia, na concepção democrática e igualitária das cidades, na qualidade de vida como também na eficiência da cidade como um todo (DUARTE; SÁNCHEZ e LIBARDI, 2017).

\subsection{JUSTIFICATIVA}

O censo demográfico realizado no ano de 2010 pelo Instituto Brasileiro de Geografia e Estatística - IBGE - estimou em pouco mais de 45 milhões a quantidade de pessoas que contam com algum tipo de deficiência, o que correspondia a aproximadamente 23,9\% da população do Brasil na época. Esses dados estão cronologicamente desatualizados sabendo que o censo demográfico é realizado a cada 10 anos, entretanto no ano de 2020 teve de ser adiado por motivos de pandemia, porém os mesmos ainda são uteis como indicadores de como é imprescindível que sejam 
atendidas as necessidades dessas pessoas, visto que não se trata de um número pequeno.

As condições das vias trafegáveis, das calçadas, do mobiliário e dos equipamentos urbanos existentes são fatores que influenciam na qualidade de vida e na mobilidade da população de uma cidade, contribuindo de forma direta com a maneira com a qual a cidade se desenvolve, já que com boas condições é possível ter uma locomoção, tanto de pessoas quanto de cargas, mais fluida e eficiente.

O atual cenário brasileiro de transporte conta com uma significante preferência dos usuários pelo transporte particular - o automóvel ou a motocicleta - frente a outros modais de transporte, os motorizados - ônibus, metrôs, trens, bondes, etc. - e os não motorizados - andar a pé, bicicleta, etc. Essa preferência acarreta efeitos caóticos tanto ao sistema de mobilidade urbana, como ao meio ambiente, intensificando os congestionamentos, aumentando a ocupação do solo, a poluição tanto visual quanto sonora e ambiental, etc.

Como alternativa para essa utilização exacerbada dos carros particulares se tem o incentivo à utilização do transporte coletivo urbano, entretanto, para que essa substituição seja efetiva, é imprescindível que esse sistema ofereça boas condições aos usuários, como, por exemplo, a existência de uma boa gestão e bom planejamento por parte do poder público, com o atendimento de toda demanda e necessidades da população, como também uma operação eficaz. Além disso, é necessário que os usuários contem com facilidade de utilização, pontos de parada e terminais acessíveis e em locais estratégicos, linhas bem planejadas, veículos em bom estado de conservação, entre tantas outras condições que raramente são atendidas.

Em se tratando da inclusão social de pessoas com deficiência, o setor dos transportes assume um papel de extrema importância, tendo em vista que a própria constituição federal garante o direito de ir e vir. Além disso, esse direito é também algo inerente ao ser humano, totalmente necessário para a vida em sociedade, sendo parte da declaração dos direitos humanos, no que se refere ao direito ao lazer. 
Nesta circunstância, é de grande valia analisar as condições do sistema de transporte coletivo urbano, salientando a atual situação dos pontos de embarque e desembarque do sistema de transporte coletivo em uma cidade do interior da Bahia, tendo como embasamento as normas técnicas de acessibilidade da ABNT, bem como a aplicação das leis que preconizem os assuntos - acessibilidade e mobilidade urbana.

\subsection{OBJETIVOS}

\subsubsection{OBJETIVO GERAL}

O objetivo geral deste trabalho é investigar os pontos de embarque e desembarque do transporte coletivo urbano no percurso de uma das 47 linhas operantes na cidade de Vitória da Conquista - BA, verificando o cumprimento da norma de acessibilidade, NBR 9050/2015, com auxílio de outras normas, como também as leis vigentes no município e em âmbito federal, sua utilização de forma adequada e o conforto promovido aos usuários com necessidades especiais e/ou mobilidade reduzida.

\subsubsection{OBJETIVOS ESPECÍFICOS}

- Explorar a eficiência dos pontos de parada do transporte coletivo, segundo a norma ABNT NBR 9050:2015;

- Realizar a análise crítica dos resultados obtidos por meio do levantamento de campo, com aquilo que é preconizado pelas normas e leis vigentes;

- Apresentar alternativas para possíveis melhorias, conformações e adaptações para a acessibilidade dos ambientes analisados, como também do sistema de transporte coletivo como um todo.

\section{FUNDAMENTAÇÃO TEÓRICA}

\subsection{ACESSIBILIDADE E INCLUSÃO SOCIAL}

A palavra acessibilidade vem do latim accessibilitas, que, de acordo com o dicionário Michaelis, refere-se à facilidade de acesso, qualidade do que é acessível. No contexto 
da inclusão social, que se trata de um conjunto de atitudes que combatem a exclusão de determinados grupos de privilégios de viver em sociedade, a acessibilidade é um ponto importante, uma vez que o direito de ir e vir é garantido ao ser humano pela Constituição Federal.

Segundo o Programa de Ação Mundial para Pessoas Deficientes (1982), da ONU, no item 21 referente à igualdade de oportunidade, é visto que:

A pessoa com deficiência se vê relegada à invalidez quando lhe são negadas as oportunidades de que dispõe, em geral, a comunidade, e que são necessárias aos aspectos fundamentais da vida, como a participação em grupos sociais e políticos, o acesso às instalações públicas, a liberdade de movimentação e o estilo geral da vida diária.

Como afirmam Brumer, Pavei e Mocelin (2004), é necessário que as pessoas, não somente as portadoras de deficiência, mas as portadoras de necessidades especiais em geral sejam consideradas e tratadas como cidadãs possuidoras de direitos e deveres, ativamente participantes e construtores da sociedade.

\subsection{MOBILIDADE URBANA}

A mobilidade urbana tem como premissa básica permitir que todos tenham condições de transitar entre as diferentes áreas de uma cidade, uma vez que as necessidades das pessoas, sejam sociais ou econômicas, fazem com que seja preciso o seu deslocamento no espaço, seja por meio de automóveis particulares ou do sistema de transporte público. De acordo com Vasconcellos, Carvalho e Pereira (2011), esses deslocamentos são feitos com maior ou menor nível de conforto de acordo com as condições específicas em que se realizam, e, ainda, implicam em consumos de tempo, espaço, energia e recursos financeiros.

Segundo Duarte, Sánchez e Libardi (2017, p. 57):

O transporte coletivo deve ser um provedor, eficaz e democrático, de mobilidade e acessibilidade urbana. Para o desenvolvimento de projetos 
deste sistema deve-se analisar simultaneamente o uso do solo, políticas de planejamento urbano e de qualidade ambiental, e desta forma possibilitar da melhor maneira a acessibilidade.

\subsection{BARREIRAS}

São barreiras arquitetônicas quaisquer obstáculos que impeçam que pessoas desfrutem e ocupem espaços físicos. De maneira geral, as limitações que tem uma pessoa com necessidades especiais no âmbito da locomoção não se referem às suas próprias limitações, mas no modo como os ambientes e serviços ao seu redor não foram projetados para acomodar suas diferenças. Ambientes abertos, como ruas, calçadas, faixas de pedestres são propícios a essas barreiras de locomoção tanto quanto ambientes fechados. (HERMONT, 2006)

\subsection{NORMAS E LEIS}

É notória uma constante evolução do Brasil em relação à criação de normas e leis que tratem sobre acessibilidade e inclusão social das pessoas portadoras de deficiência e com mobilidade reduzida, garantindo cada vez mais a igualdade da sociedade.

\subsubsection{NORMAS TÉCNICAS}

A Associação Brasileira de Normas Técnicas - ABNT - formulou a sua primeira normativa relacionada à acessibilidade, a NBR 9050, em 2004. A sua versão mais recente e que se encontra em vigor é a de 2015, denominada de ABNT NBR 9050:2015 - Acessibilidade a edificações, mobiliário, espaços e equipamentos urbanos. É nessa norma que se encontram disponíveis diretrizes e recomendações de critérios e parâmetros que deverão ser analisados para a elaboração de um projeto acessível, apresentando modelos, dimensões mínimas e máximas para ambientes, entre outros. Segundo essa norma, tem-se as seguintes definições:

Acessibilidade: possibilidade e condição de alcance, percepção e entendimento para utilização, com segurança e autonomia, de espaços, 
mobiliários, equipamentos urbanos, edificações, transportes, informação e comunicação, inclusive seus sistemas e tecnologias, bem como outros serviços e instalações abertos ao público, de uso público ou privado de uso coletivo, tanto na zona urbana como na rural, por pessoa com deficiência ou mobilidade reduzida.

Acessível: espaços, mobiliários, equipamentos urbanos, edificações, transportes, informação e comunicação, inclusive seus sistemas e tecnologias ou elemento que possa ser alcançado, acionado, utilizado e vivenciado por qualquer pessoa.

A NBR 16537/2016 denominada Acessibilidade - sinalização tátil no piso, foi elaborada à luz da NBR 9050/2015 e apresenta algumas diretrizes específicas para o piso tátil localizado no piso,

É estabelecido nesta norma critérios e parâmetros técnicos observados para a elaboração do projeto e instalação de sinalização tátil no piso sejam para construção ou adaptação de edificações, espaços e equipamentos urbanos às condições de acessibilidade para a pessoa com deficiência visual ou surdo-cegueira. (ABNT, 2016, p. 1).

Quanto aos veículos, tem-se a norma da ABNT NBR 14022 - Transporte: Acessibilidade à pessoa portadora de deficiência em ônibus e trólebus, para atendimento urbano e intermunicipal, o objetivo desta norma é de "estabelecer os padrões e critérios que visam proporcionar à pessoa portadora de deficiência acessibilidade ao transporte em ônibus e trólebus, para atendimento urbano e intermunicipal." (NBR 14022, 2011).

\subsubsection{LEIS}

Uma das leis federais que preconiza o assunto é a Lei ㄲo 7.853 de 1989, é tratado nessa lei sobre a Política Nacional para a Integração da Pessoa com Deficiência, onde 
são estabelecidas normas gerais para garantir os direitos destas pessoas e a sua adequada integração social.

A lei federal que trata sobre a mobilidade urbana é a Lei 12.587/12. "Na Lei, são definidos e classificados os modos e serviços de transporte, além de exemplificadas infraestruturas de mobilidade urbana que compõem o Sistema Nacional de Mobilidade Urbana." (POLÍTICA NACIONAL DE MOBILIDADE URBANA, 2013).

O município de Vitória da Conquista tem seus serviços estabelecidos à luz da Lei 10098:2000 que trata da promoção da acessibilidade das pessoas portadoras de deficiência ou com mobilidade reduzida. Essa lei traz a seguinte definição para o termo acessibilidade:

Acessibilidade: possibilidade e condição de alcance para utilização, com segurança e autonomia, de espaços, mobiliários, equipamentos urbanos, edificações, transportes, informação e comunicação, inclusive seus sistemas e tecnologias, bem como de outros serviços e instalações abertos ao público, de uso público ou privados de uso coletivo, tanto na zona urbana como na rural, por pessoa com deficiência ou com mobilidade reduzida.

Nessa mesma Lei é possível encontrar também outras definições pertinentes, tais como:

Pessoa com deficiência: aquela que tem impedimento de longo prazo de natureza física, mental, intelectual ou sensorial, o qual, em interação com uma ou mais barreiras, pode obstruir sua participação plena e efetiva na sociedade em igualdade de condições com as demais pessoas;

Pessoa com mobilidade reduzida: aquela que tenha, por qualquer motivo, dificuldade de movimentação, permanente ou temporária, gerando redução efetiva da mobilidade, da flexibilidade, da coordenação motora ou da percepção, incluindo idoso, gestante, lactante, pessoa com criança de colo e obeso. 
Em 1994, formulou-se a Lei o 802/1994, que dispõe sobre o horário de atendimento ao usuário do transporte coletivo urbano. Já em 1990, criou-se a Lei ํㅜ 520/1990 que autoriza reserva de lugares em transportes coletivos a pessoas indicadas. No ano de 1999, foi instaurada no município a Lei no 968/1999, que dispõe sobre o sistema municipal de transporte público e regulamenta a prestação do serviço de transporte coletivo. O município conta com algumas outras leis que auxiliam no regimento do TCU.

\subsection{PARÂMETROS ANTROPOMÉTRICOS}

A norma ABNT NBR 9050:2015 traz as seguintes prescrições:

\subsubsection{PESSOA COM CADEIRA DE RODAS E CÃO GUIA}

A Figura 1 expõe as dimensões recomendáveis para cadeiras de rodas, sejam elas manuais ou motorizadas.

Figura 1 - Cadeira de rodas manual, motorizada e esportiva.

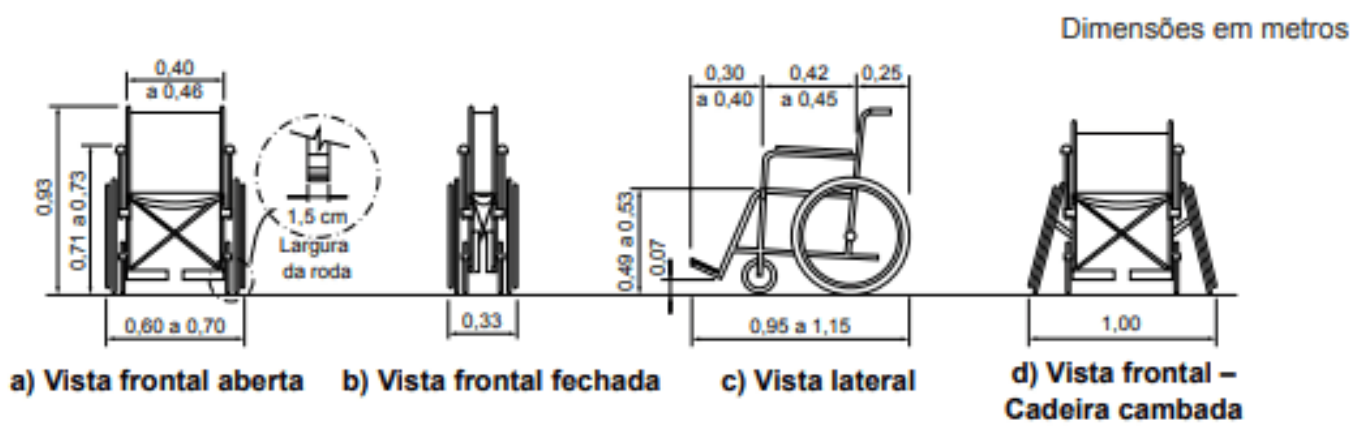

Fonte: ABNT NBR 9050:2015

\subsubsection{PESSOA EM PÉ}

São indicadas na Figura 2 a seguir as dimensões recomendáveis para a realização do deslocamento de pessoas em pé. 
Figura 2 - Dimensões referenciais para deslocamento de pessoas em pé.

Dimensð̄es em metros

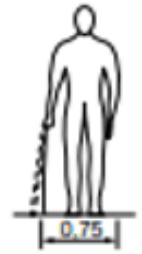

a) Uma bengala

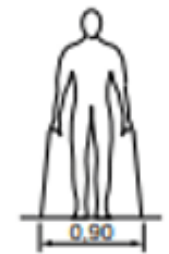

b) Duas bengalas

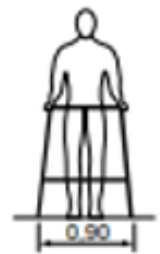

c) Andador com rodas

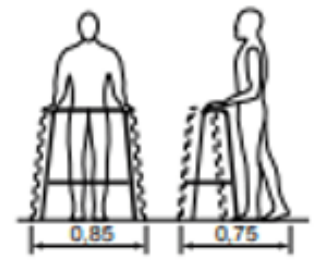

d) Andador rigido - Vistas frontal e lateral

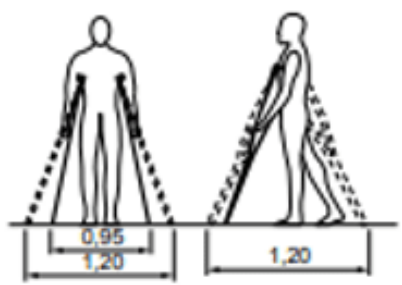

e) Muletas - Vistas frontal e lateral

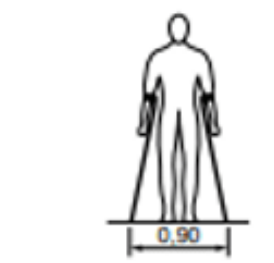

f) Muletas tipo canadense

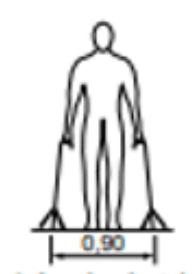

g) Apoio de tripé

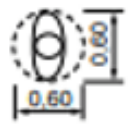

h) Sem órtese

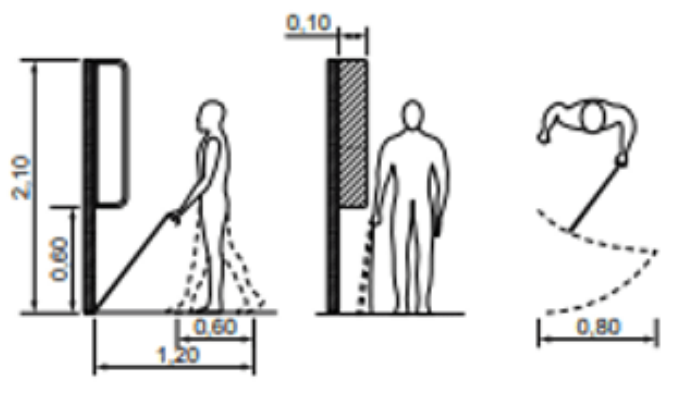

i) Bengala longa - Vistas lateral, frontal e superior

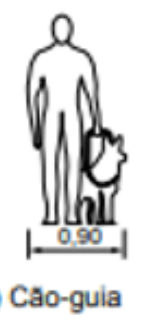

RC: 50831

Disponível em: https://www.nucleodoconhecimento.com.br/engenharia-civil/transporte-coletivo 


\subsubsection{MÓDULO DE REFERÊNCIA}

É considerada como o módulo de referência a projeção de $80 \mathrm{~cm}$ por $120 \mathrm{~cm}$ no piso, que equivale a uma Pessoa em Cadeira de Rodas - PCR - motorizada ou não, ilustrado na Figura 3.

Figura 3 - Dimensões do módulo de referência (M.R.).

Dimensőes em metros

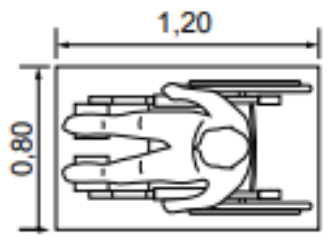

Fonte: ABNT NBR 9050:2015

\subsubsection{MANOBRA DE RODAS COM DESLOCAMENTO}

Para que uma Pessoa com Cadeira de Rodas possa realizar um deslocamento, é necessário que se tenham algumas dimensões mínimas, essas dimensões são apresentadas na norma para três situações distintas, tais como são mostradas nas Figuras 4 e 5 : 
Figura 4 - Largura para deslocamento em linha reta.

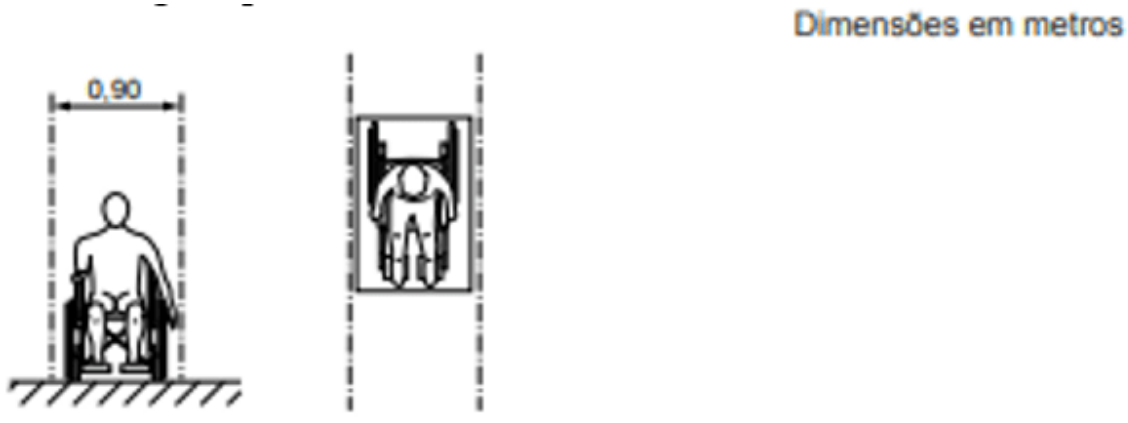

a) Uma pessoa em cadeira de rodas - Vistas frontal e superior
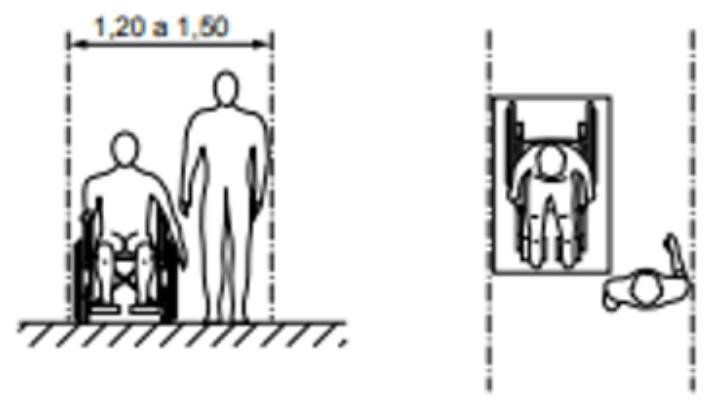

b) Um pedestre e uma pessoa em cadeira de rodas - Vistas frontal e superior
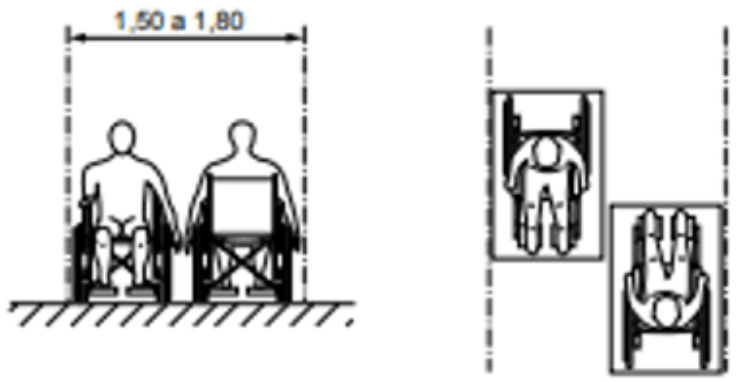

c) Duas pessoas em cadeira de rodas - Vistas frontal e superior

Fonte: ABNT NBR 9050:2015 
Figura 5 - Transposição de obstáculos isolados.

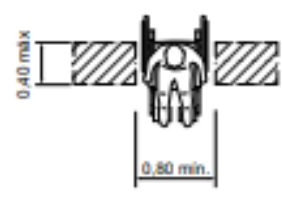

a) Vista superior

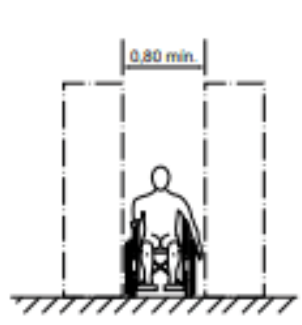

b) Vista frontal

Dimensठ̄es em metros

Fonte: ABNT NBR 9050:2015

\subsubsection{SINALIZAÇÃO TÁTIL DIRECIONAL E DE ALERTA}

Sabe-se que o piso tátil tem a função de indicar o caminho que pode e deverá ser percorrido pelas pessoas que contam com alguma necessidade especial ou mobilidade reduzida, sendo este o caminho pelo qual essas pessoas podem percorrer sem se deparar com nenhum obstáculo. Segundo a ABNT NBR 9050 (2015), a sinalização tátil e visual de alerta deve ser utilizada para:

a) informar à pessoa com deficiência visual sobre a existência de desníveis ou situações de risco permanente, como objetos suspensos não detectáveis pela bengala longa;

b) orientar o posicionamento adequado da pessoa com deficiência visual para o uso de equipamentos, como elevadores, equipamentos de autoatendimento ou serviços;

c) informar as mudanças de direção ou opções de percursos;

d) indicar o início e o término de degraus, escadas e rampas;

e) indicar a existência de patamares nas escadas e rampas;

f) indicar as travessias de pedestres.

A Figura 6 ilustra as dimensões base para a sinalização tátil de alerta. 
Figura 6 - Sinalização tátil de alerta e relevos táteis de alerta instalado no piso.

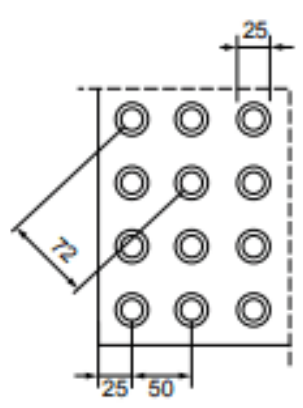

a) Piso

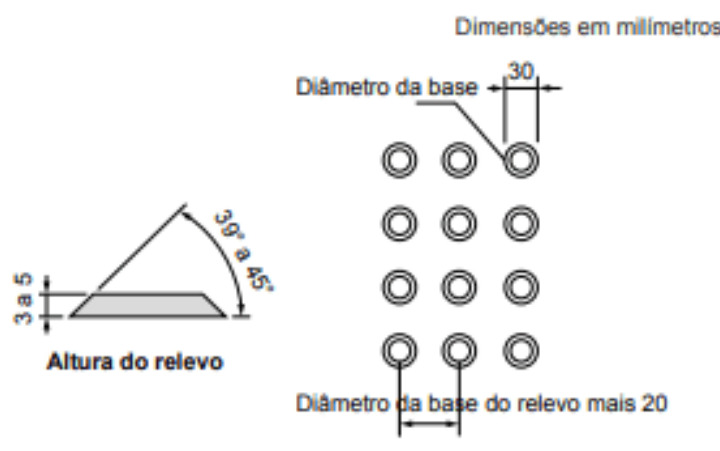

b) Relevos

Fonte: ABNT NBR 9050:2015

\subsubsection{SINALIZAÇÃO VISUAL}

A sinalização visual é realizada por meio de mensagens de textos, contrastes, símbolos e figuras, e tem o objetivo de orientar não somente as pessoas com necessidades especiais ou mobilidade reduzida, mas também aquelas que não possuem limitações, a fim de evitar que interfiram na locomoção dessas pessoas por determinados ambientes (NBR 9050, 2015).

\subsection{SÍMBOLOS}

São representações visuais que, por meio de uma imagem ou uma forma geométrica normalizada, criam uma metáfora entre o objeto e a informação de sua representação, e passam alguma informação ou mensagem (NBR 9050, 2015).

\subsubsection{SÍMBOLO INTERNACIONAL DE ACESSO - SIA}

A indicação de acessibilidade nas edificações, no mobiliário, nos espaços urbanos e nos equipamentos deve ser feita através dos seguintes símbolos, (MURATA, 2015), preconizados pela norma de acessibilidade, como mostram as Figuras 7, 8 e 9: 
Figura 7 - Símbolo Internacional de acesso - Forma A.

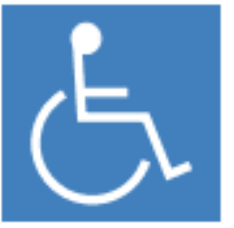

a) Branco sobre fundo azul

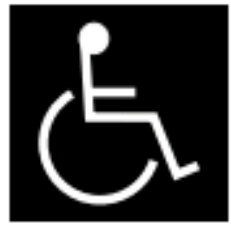

b) Branco sobre fundo preto

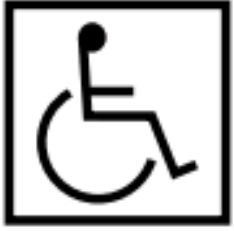

c) Preto sobre fundo branco

Fonte: ABNT NBR 9050:2015

Figura 8 - Símbolo internacional de pessoas com deficiência visual.

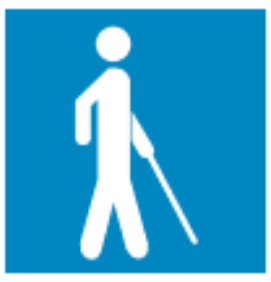

a) Branco sobre fundo azu

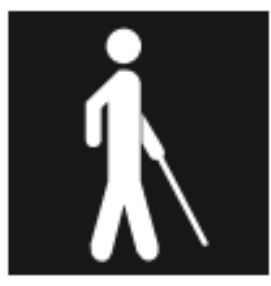

b) Branco sobre fundo preto

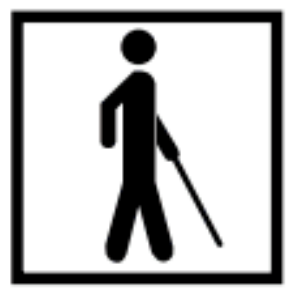

c) Preto sobre fundo branco

Fonte: ABNT NBR 9050:2015

Figura 9 - Símbolo internacional de pessoas com deficiência auditiva.

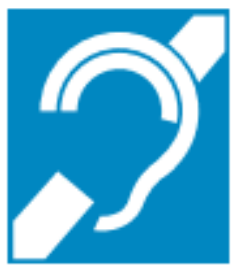

a) Branco sobre fundo azul

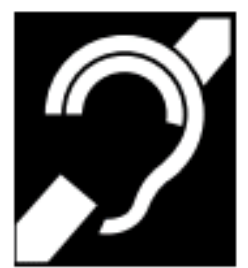

b) Branco sobre fundo preto

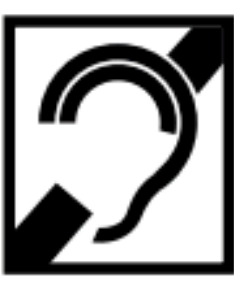

c) Preto sobre fundo branco

Fonte: ABNT NBR 9050:2015 


\subsubsection{SÍMBOLO INTERNACIONAL DE ACESSO INDICAÇÃO EXTERNA NO VEÍCULO}

A norma de acessibilidade traz também as indicações relativas ao posicionamento do Símbolo Internacional de Acessibilidade nos ônibus coletivos, tais como são indicados nas Figuras 10 e 11:

Figura 10 - Exemplos de localização do SIA na lateral do veículo.
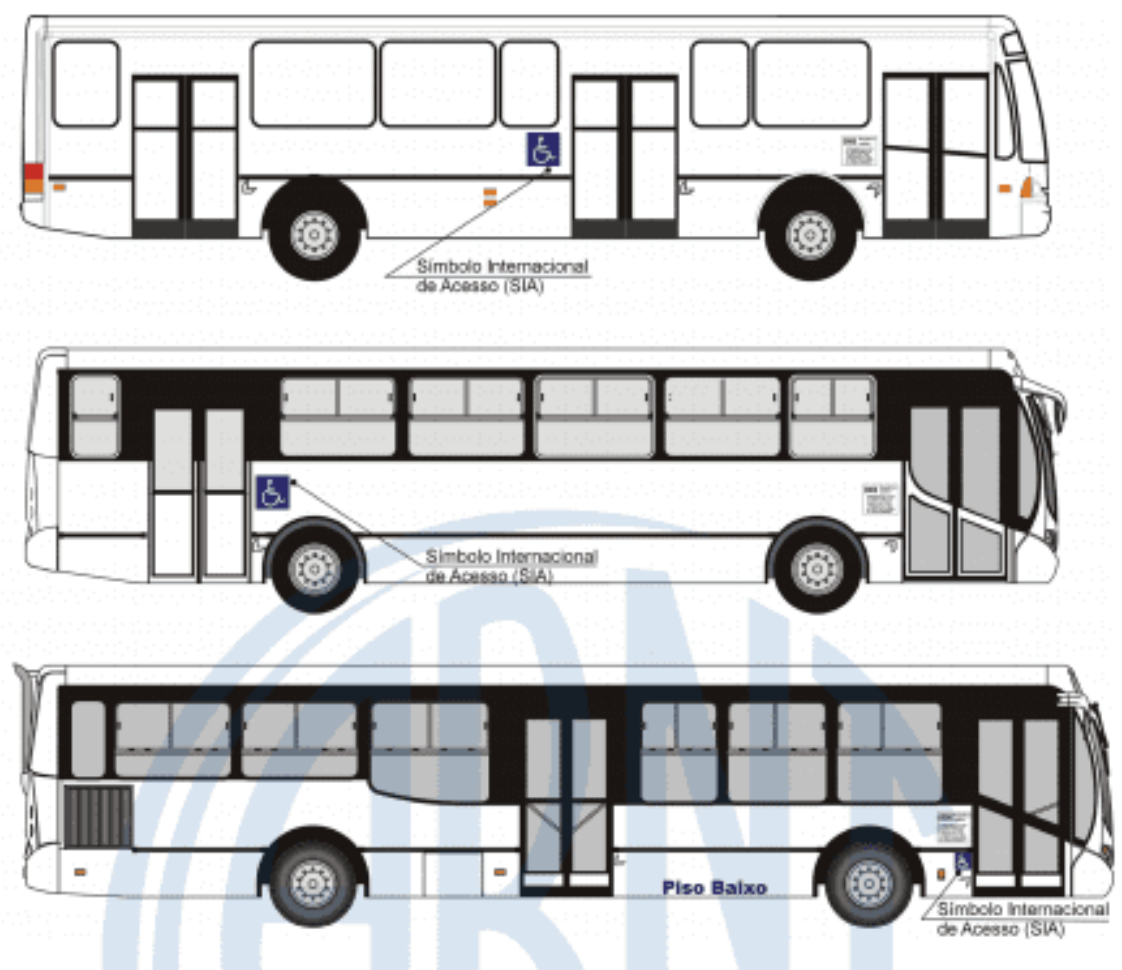

Fonte: ABNT 14022:2011 
Figura 11 - Exemplos de localização do SAI na parte dianteira do veículo.

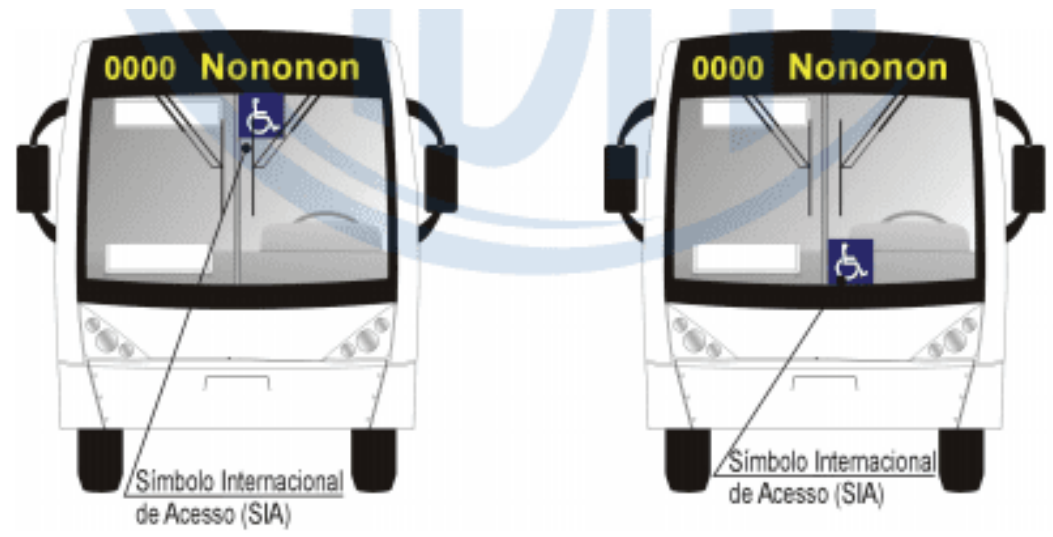

Fonte: ABNT NBR 14022:2011

\subsection{DESENHO UNIVERSAL}

Trata-se da idealização de produtos, ambientes, programas e serviços que possibilitem a equiparação do uso por todas as pessoas sem necessidade de alguma adaptação ou planejamento específico (CAMARGO, 2017).

\subsection{CARACTERÍSTICAS DO TRANSPORTE ACESSÍVEL}

\subsubsection{PONTOS DE EMBARQUE E DESEMBARQUE}

A NBR 9050:2015 traz a seguinte informação referente aos pontos de embarque e desembarque de transporte público, "Na implantação de ponto de embarque e desembarque de transporte público, deve ser preservada a faixa livre na calçada. Nenhum de seus elementos pode interferir na faixa livre de circulação de pedestres".

A NBR 14022 (2011) traz algumas considerações a respeito aos pontos de parada do TCU como também dos terminais, tais como:

O ponto de parada no passeio público deve estar integrado com o entorno, respeitando uma faixa livre mínima de $1200 \mathrm{~mm}$ em condições de segurança e conforto para circulação de pedestres e pessoas com deficiência em cadeira de rodas. Na falta de espaço suficiente, admite- 
se uma faixa livre de $900 \mathrm{~mm}$. Os pontos de parada devem ser providos de assento e espaço para cadeira de rodas de acordo com a ABNT NBR 9050. Recomenda-se a adoção de cobertura. Para garantir a manobra da cadeira de rodas, devem ser eliminadas interferências físicas no ponto de parada.

A circulação interna no terminal deve ser projetada de forma a organizar os fluxos de usuários, prevendo-se áreas de refúgio e evacuação em casos de emergência, conforme a ABNT NBR 9077. O terminal deve ter no mínimo $20 \%$ dos assentos disponíveis para uso das pessoas com deficiência ou mobilidade reduzida, localizados próximos aos locais de embarque, identificados e sinalizados.

\subsubsection{GUIA DE DESIGN URBANO}

Esse guia foi desenvolvido em conjunto pela Associação Nacional de Transporte dos Estados Unidos - NATCO - e pelo Global Designing Cities Initiative e apresenta as seguintes dicas para a construção de um ponto de ônibus acessível e adequado:

- Área proporcional - Aconselha-se que os pontos de parada sejam dimensionados em função do fluxo de usuários e a frequência dos mesmos, com o objetivo de garantir que todos os usuários consigam se abrigar no ponto, sem precisar avançar para fora da estrutura enquanto esperam.

- Local seguro - O acesso dos usuários ao ponto de embarque e desembarque deve ser feito de maneira segura pela calçada, sem nenhum obstáculo ou barreira, e deve contar com uma faixa de pedestres nas proximidades.

- Faixa de pedestres: É recomendável também que a faixa esteja localizada atrás do ponto de parada do ônibus para evitar acidentes, já que nessa posição o pedestre tem total visão da rua e do trânsito.

- Cobertura: É necessária a instalação de uma cobertura nos pontos de parada para proteger os usuários das intempéries.

- Bem sinalizado - Os pontos de paradas devem ser bem sinalizados, a fim de evitar que veículos particulares ou outros utilizem o espaço destinado aos 
ônibus, e também devem contar com sinalizações informativas, tais como: linhas de ônibus que passam naquele determinado ponto, itinerário, etc.

- Faixas exclusivas - O guia defende a eficiência de canaletas exclusivas para ônibus, ao passo que elas aumentam a fluidez do trânsito, já que os ônibus não precisam trocar de faixa para realizar o embarque e desembarque de passageiros e nem lidar com outros veículos.

O caderno técnico de projeto de mobilidade urbana, desenvolvido elo governo federal para sistemas de prioridade ao ônibus apresenta ainda um modelo para esse ponto de ônibus ideal, tal qual é indicado na Figura 12.

Figura 12 - Ponto de ônibus ideal

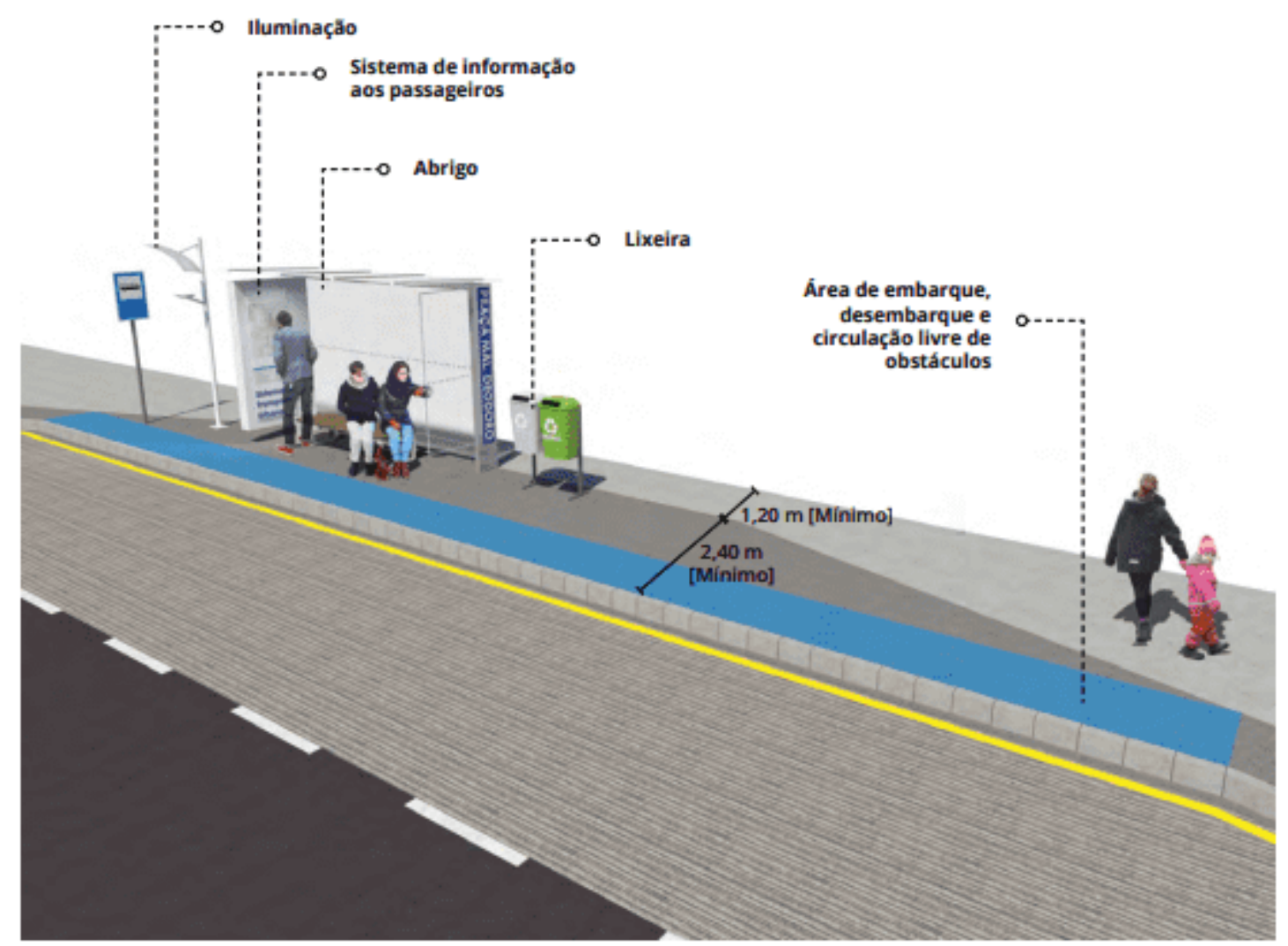

Fonte - Caderno Técnico para Projetos de Mobilidade Urbana (2016) 


\section{PROCEDIMENTOS METODOLÓGICOS}

Diante do exposto, essa pesquisa foi elaborada através de uma pesquisa teórica e de campo de caráter descritivo observacional com o objetivo de expor de forma qualiquantitativa a situação dos pontos de parada do sistema de transporte coletivo urbano em um trecho específico de uma das 47 linhas que estão em operação no município de Vitória da Conquista - BA quanto à acessibilidade.

Os dados foram coletados através da interação direta entre os autores e os locais a serem analisados. A Figura 13 expõe o passo a passo da pesquisa.

Figura 13 - Diagramação das etapas da pesquisa.

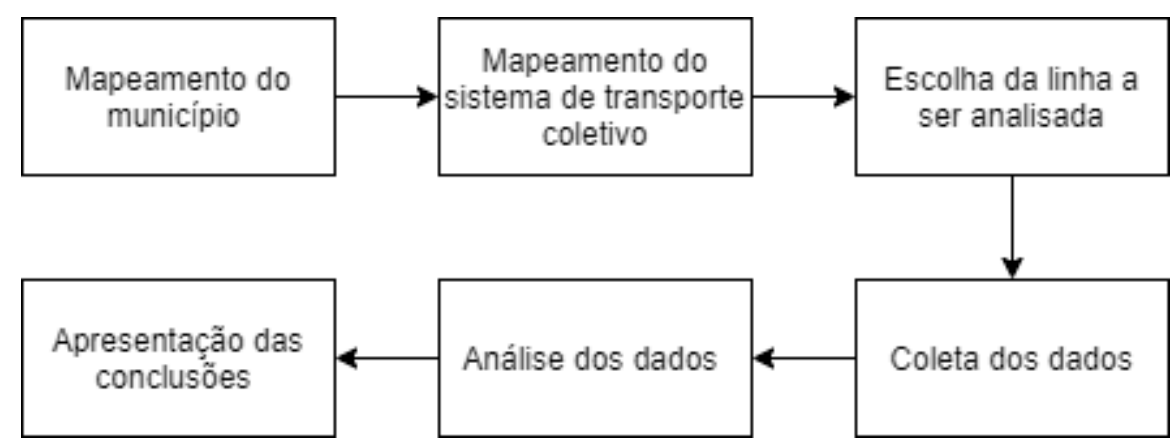

Fonte: Elaborada pelos autores

- Mapeamento do município - Dados estatísticos do município, como localização, área, população fixa e flutuante. Dados do sistema de transporte coletivo urbano (TCU), como quantidade de linhas, itinerário, quantidade de veículos que compõem a frota, de veículos acessíveis, de pontos de parada, etc.;

- Mapeamento do sistema de TCU - Análise feita em conjunto com o mapeamento do município;

- Escolha da linha a ser analisada - Elaboração de critérios para que seja realizada a escolha de uma linha de ônibus que represente boa parte da população ao mesmo tempo em que percorre um trajeto significativo para a pesquisa. 
- Coleta de dados - Coleta de dados específicos da linha selecionada, observando aspectos como quantidade e estado dos pontos de parada, do terminal de ônibus, entre outros;

- Análise dos dados;

- Apresentação das conclusões - Exposição do que foi concluído através da pesquisa teórica baseada nas normas e leis e no levantamento feito em campo.

\section{RESULTADOS E DISCUSSÕES}

\subsection{VITÓRIA DA CONQUISTA - BAHIA}

\subsubsection{DADOS ESTATÍSTICOS}

O município de Vitória da Conquista, apresentado em forma de mapa na Figura 14, está localizado na região centro-sul do estado baiano e a $509 \mathrm{~km}$ da capital Salvador. Com uma área de $3.705,838$ km² (IBGE, 2019).

Figura 14 - Mapa de Vitória da Conquista - BA

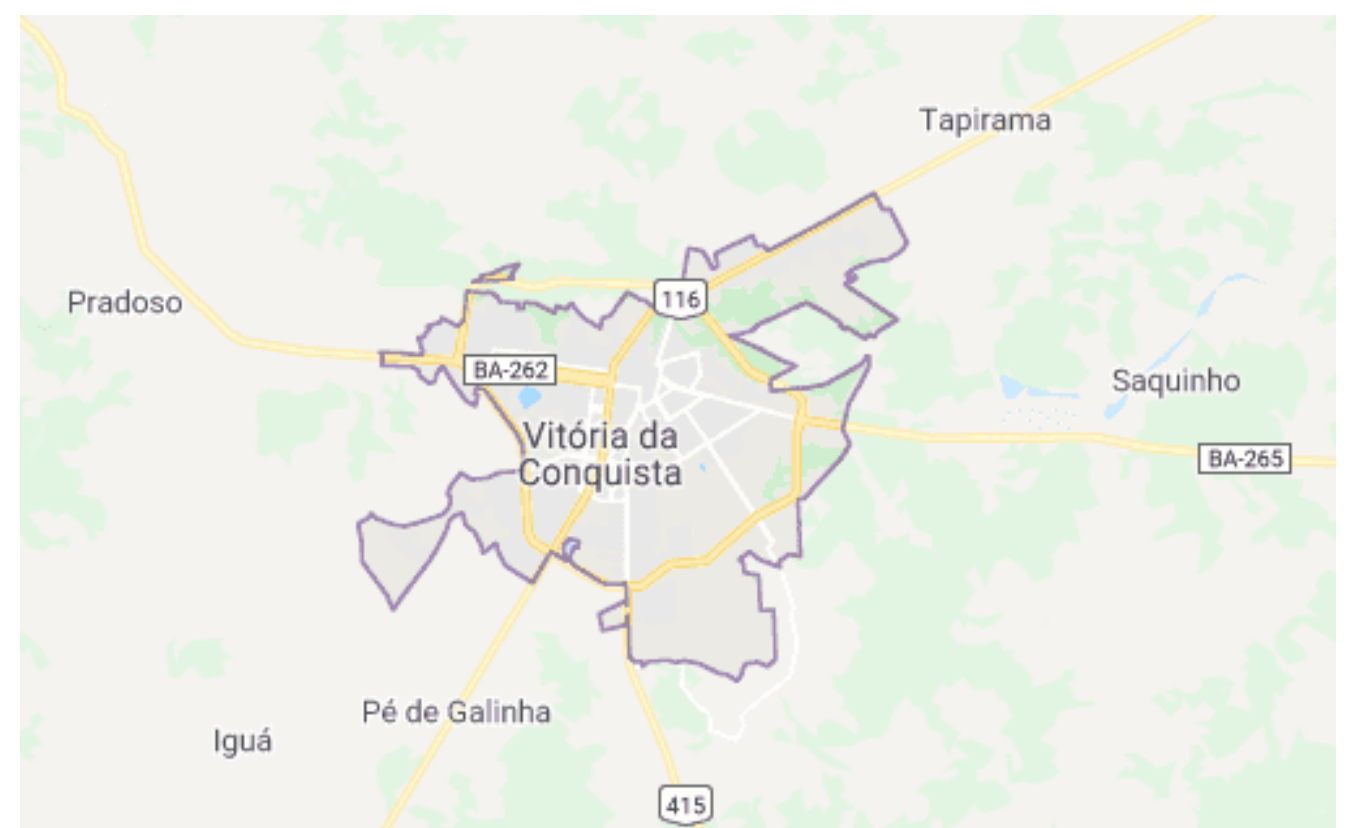

Fonte: Recorte do Google Maps elaborado pelos autores 
A população de conquista, segundo o IBGE (2019) é estimada em 338.480 habitantes para população fixa residente no município, sendo que a Prefeitura Municipal estima que por dia haja na cidade um número próximo a 40.000 habitantes flutuantes desfrutando dos serviços e oportunidades de emprego, educação, lazer, entre outros, da cidade em questão. Visto isso, é perceptível a grandiosidade da cidade e a importância da boa prestação de serviços básicos, tais como a locomoção.

\subsection{LINHAS E ROTAS DO SISTEMA DE TRANSPORTE COLETIVO}

O sistema de transporte urbano de Vitória da Conquista conta com 49 linhas de ônibus, sendo 47 em estado de operação, elencadas no Quadro 1. Esse serviço é prestado por duas empresas privadas que contam com um total de 152 veículos, todos adaptados e acessíveis, segundo dados disponibilizados pela Prefeitura Municipal.

Quadro 1 - Linhas de ônibus operantes no município

\begin{tabular}{|c|c|c|c|}
\hline Ônibus & Rota & Ônibus & Rota \\
\hline D30 & Vilas Serranas $x$ UESB & D32 & Aparecida $\times$ UESB \\
\hline D33 & Conquista VI x UESB & D34 & Patagônica x UESB \\
\hline D35 & Rodoviária x UESB & D36 & $\begin{array}{l}\text { Moradas dos Pássaros } \mathrm{x} \\
\text { UESB }\end{array}$ \\
\hline D39 & Miro Cairo x UESB & D40 & Jardim Valéria x UESB \\
\hline D44 & B. Brasil x Jd. Candeias & $\mathrm{P} 60$ & Vilas Serranas x Conquista VI \\
\hline P52 & Conquista VI x UESB & P54 & Morada Real x Miro Cairo \\
\hline R01 & Vilas Serranas $x$ Centro & R02 & Cidade Maravilhosa x Centro \\
\hline R03 & Pradoso $\times$ Centro & R04 & Santa Marta $\times$ Centro \\
\hline R05 & Bruno Bacelar x Centro & R06 & Senhorinha Cairo $\times$ Centro \\
\hline R07 & Nova Cidade $x$ Centro & R08 & Henriqueta Prates $\times$ Centro \\
\hline R09 & UESB x Centro & R10 & Campinhos $x$ Centro \\
\hline R11 & Conveima I x Centro & R12 & Patagônia x Centro \\
\hline R13 & Guarani $\times$ Centro & R14 & Jardim Valéria x Centro \\
\hline R15 & Morada Real x Centro & R16 & Conquista VI x Centro \\
\hline
\end{tabular}




\begin{tabular}{|c|c|c|c|}
\hline R17 & $\begin{array}{l}\text { Lagoa das Flores } \mathrm{x} \\
\text { Centro }\end{array}$ & R18 & Boa vista $\times$ Centro \\
\hline R19 & Rodoviária x Centro & R20 & Cidade Modelo x Centro \\
\hline R21 & Ibirapuera x Centro & R22 & $\begin{array}{l}\text { Morada dos Pássaros } x \\
\text { Centro }\end{array}$ \\
\hline R23 & Vila América x Centro & R24 & Cruzeiro $\times$ Centro \\
\hline $\mathbf{R} 25$ & Miro Cairo x Centro & R27 & Campo Verde $x$ Centro \\
\hline R61 & Primavera $\times$ Centro & R62 & Alto Maron x Centro \\
\hline R63 & Nova Cidade x Centro & R64 & Vila Bonita $\times$ Centro \\
\hline R65 & Aeroporto x Centro & R66 & UESB $\times$ Centro \\
\hline E01 & Campinhos $x$ Dass & E03 & Alto Maron x Dass \\
\hline E04 & Miro Cairo x Dass & \multicolumn{2}{|c|}{ Total de linhas $=47$} \\
\hline
\end{tabular}

Fonte: Elaborado pelos autores

\subsection{CRITÉRIOS PARA A ESCOLHA DA LINHA}

Para a escolha de qual linha seria mais relevante para estudo, foram levados em consideração alguns critérios, tais como:

- Percurso feito pelo ônibus;

- Quantidade média de usuários por dia;

- Quantidade média de usuários portadores de alguma deficiência ou mobilidade reduzida;

- Linha que interceptasse o terminal central na sua rota;

- Linha que tivesse em sua rota lugares relevantes para o trabalho, como por exemplo, clinicas de atendimento especializado.

\subsection{CARACTERÍSTICAS DA LINHA DE ÔNIBUS ESCOLHIDA}

A linha de ônibus escolhida para ser estudada foi a D44, com rota Bairro Brasil x Bairro Jardim Candeias, caracteriza-se como sendo uma linha de caráter diametral, já que liga dois bairros distintos e passa pela Estação de Transbordo da Avenida Lauro de 
Freitas. A citada linha conta com quatro ônibus em operação durante a semana e operacional reduzido durante os finais de semana e feriados, em seu percurso existem cerca de 50 pontos de parada, incluindo a estação de transbordo comumente conhecida como terminal de ônibus, que está localizado no centro da cidade.

Essa linha é utilizada diariamente por usuários portadores de deficiência e mobilidade reduzida devido ao fato de constar em seu percurso lugares como APAE (Associação de Pais e Amigos dos Excepcionais), ACIDE (Associação Conquistense de Integração do Deficiente), entre outros estabelecimentos especializados.

A Figura 15 apresenta um mapa com visão geral do itinerário da linha D44, onde é possível observar que a mesma cobre uma parte considerável do município, o que justifica a escolha.

Figura 15 - Mapa do itinerário da linha D44 de ônibus

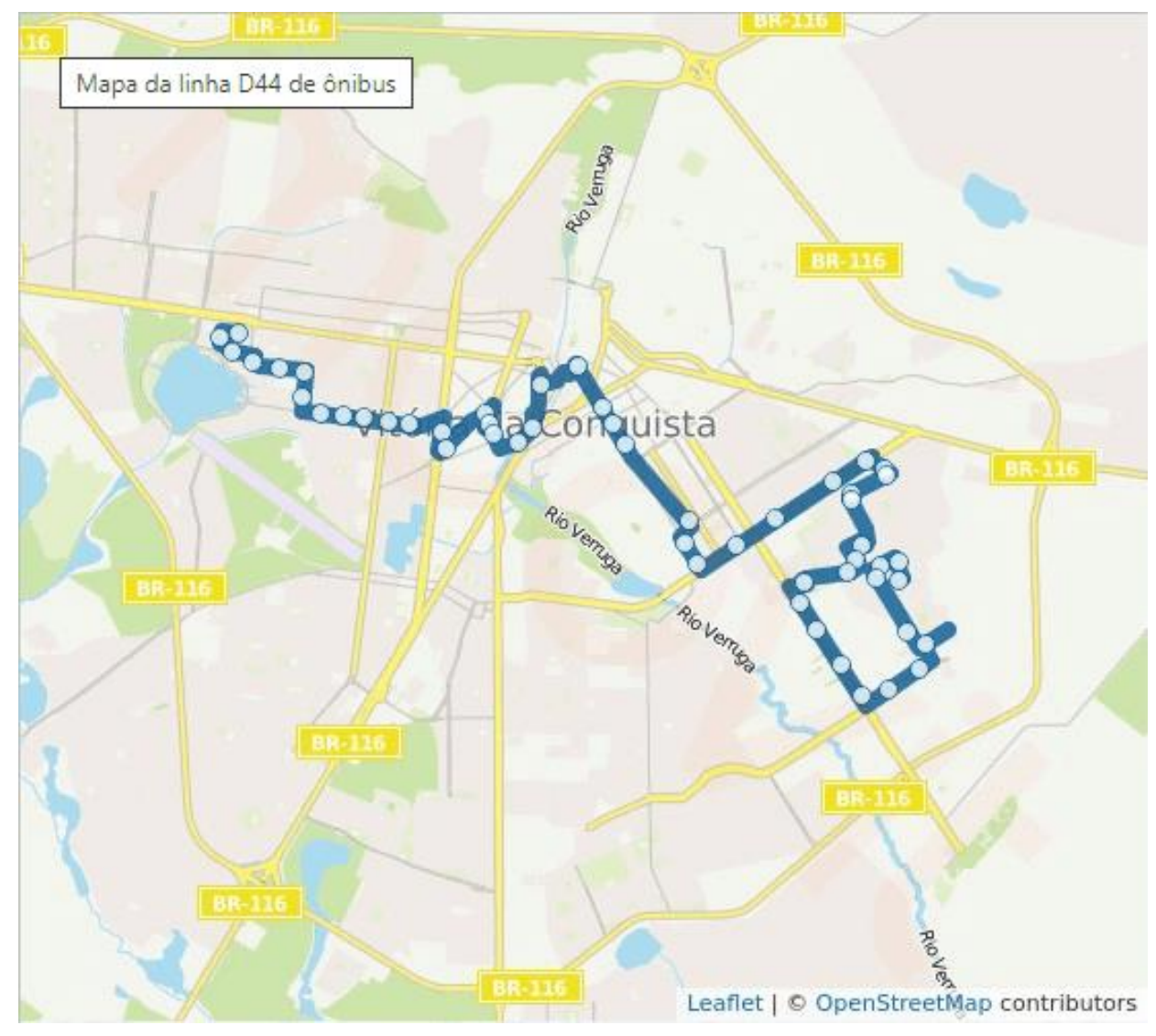

Fonte: https://moovitapp.com/ 


\subsubsection{CARACTERÍSTICAS DOS PONTOS DE PARADA E TERMINAL}

A linha Bairro Brasil x Bairro Jardim Candeias tem como trecho mais relevante o sentido de ida do Terminal de ônibus até o Bairro Jardim Candeias quando se leva em consideração o número de usuários da linha com algum tipo de deficiência ou mobilidade reduzida, sendo esse o trecho admitido para estudo neste trabalho.

No período de realização dessa pesquisa, o terminal de ônibus da cidade estava passando por reforma, por isso não são apresentados dados atualizados a respeito do mesmo, entretanto, antes da reforma, era possível observar que as condições do terminal, mesmo contendo abrigo, assento e cobertura, deixavam a desejar, equipamentos urbanos velhos e danificados, sem mencionar a condição das vias trafegáveis.

A reforma foi aprovada através de processo licitatório e com financiamento da Caixa Econômica Federal. Segundo o edital da reforma espera-se obter uma estação completamente nova, reformando desde as calçadas e o mobiliário até a realização de alterações do tráfego das vias próximas, tudo feito de maneira a efetivar o funcionamento do TCU. No edital constam algumas mudanças tais como

A estação será inteiramente coberta, inclusive nas laterais, oferecendo proteção contra o sol e a chuva. O piso será de concreto armado, e as calçadas serão revigoradas pensando na acessibilidade. Nova iluminação e paisagismo também integrarão as mudanças, que visam mais segurança e conforto para os usuários do sistema de transporte coletivo e aos pedestres que circulam na área. (SECRETARIA DE INFRAESTRUTURA URBANA, 2020).

O modelo padrão de abrigo que está sendo comumente instalado no município possui perfil metálico com fechamentos laterais e cobertura em policarbonato, assento fixo para descanso e espaço reservado para pessoa em cadeira de rodas e com iluminação e sinalização adequada. Para o trecho analisado foram encontrados 4 pontos com configuração próxima à descrita no modelo. A Figura 16 traz um desses 
pontos onde está faltando apenas lixeira e a sinalização adequada que nesse caso faz-se dispensável já que o ponto encontra-se em faixa adicional reservada somente para ônibus.

Figura 16 - Ponto faltando apenas a lixeira

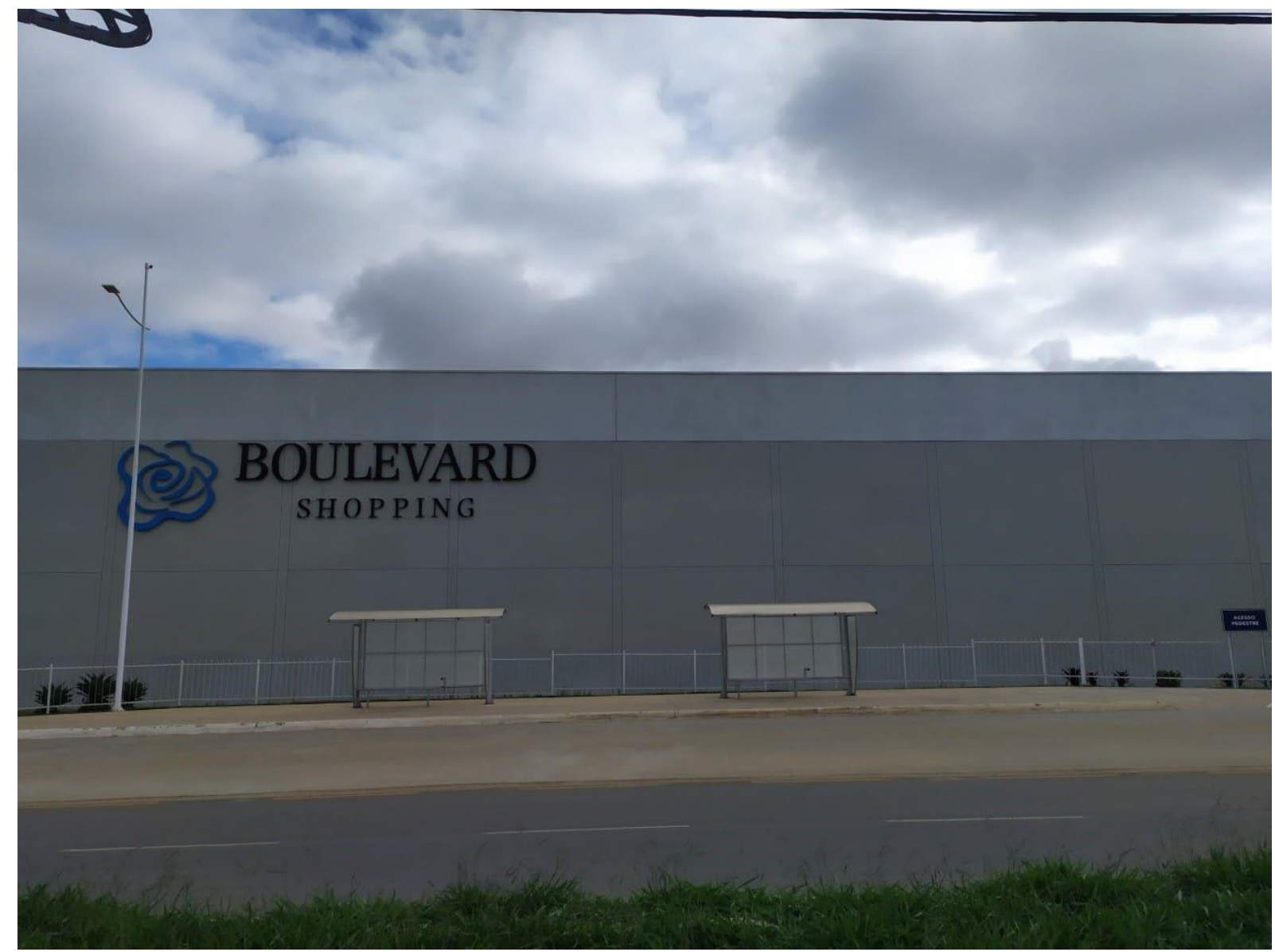

Fonte: Elaborada pelos autores

A Figura 16 apresentada anteriormente apresenta os pontos de embarque e desembarque situados na proximidade do Shopping Boulevard, pontos esses que contam com abrigo, iluminação, assento, espaço reservado para PCR, piso tátil e rampa de acesso na calçada, melhor indicada na Figura 17. Esse ponto foi construído de maneira privada pela administração do shopping citado e cedida à Prefeitura do município. 
Figura 17 - Rampa de acesso ao ponto de ônibus

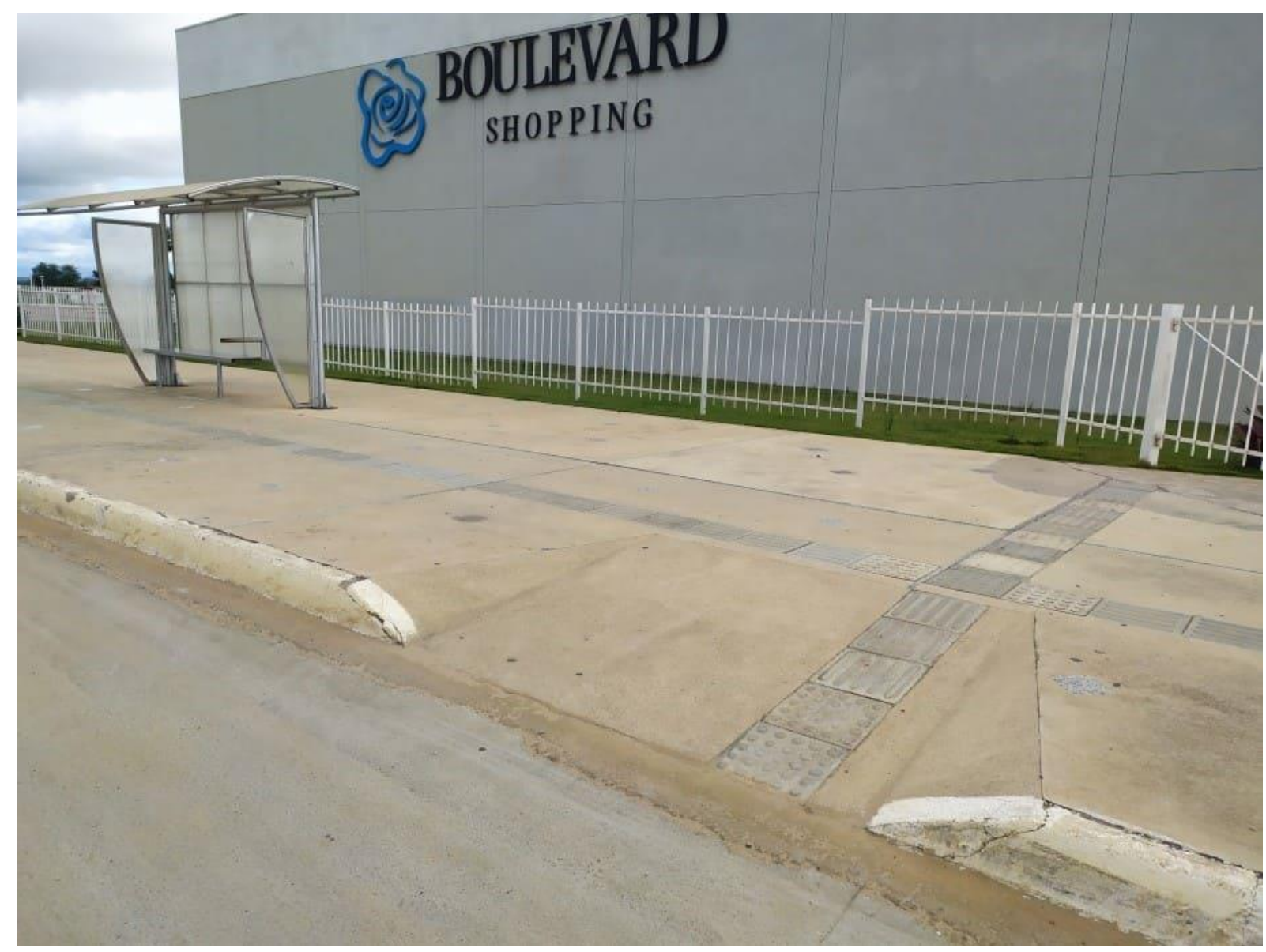

Fonte: Elaborada pelos autores

Na Figura 18, mostrada a seguir, é representado o modelo de ponto de ônibus recorrente neste trecho, foram encontrados 9 pontos iguais a esse, que contam apenas com a sinalização visual com a utilização de hastes metálicas com a placa indicando ponto de parada. 
Figura 18 - Ponto com haste metálica e placa indicativa

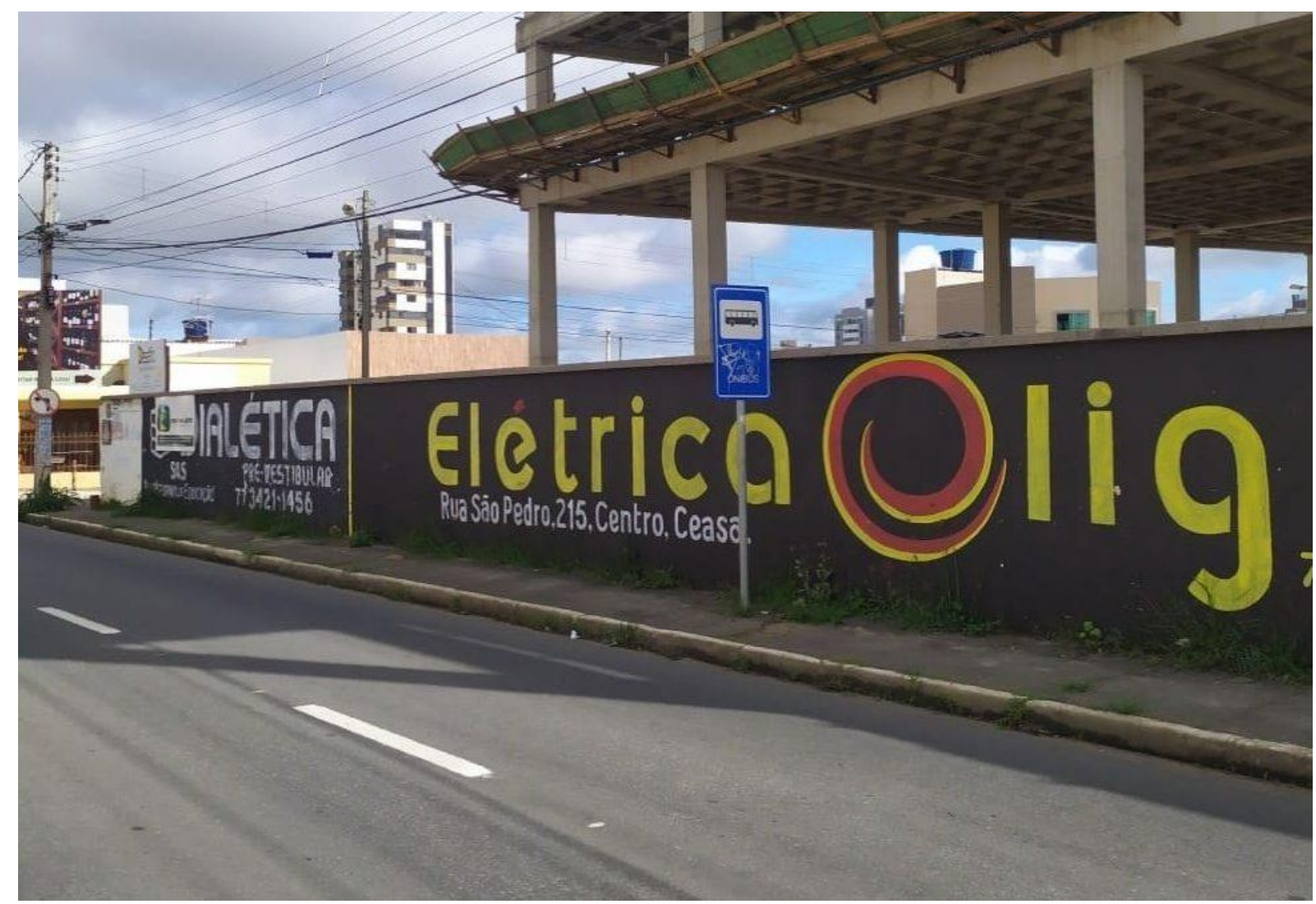

Fonte: Elaborada pelos autores

Alguns pontos de parada desse trecho contam apenas com a sinalização visual, entretanto, diferentemente do exemplo mostrado anteriormente, esta é feita não por hastes com a placa, mas sim com a placa fixada em um poste de iluminação, como é apresentado na Figura 19. 
Figura 19 - Ponto com placa indicativa fixada em poste de iluminação

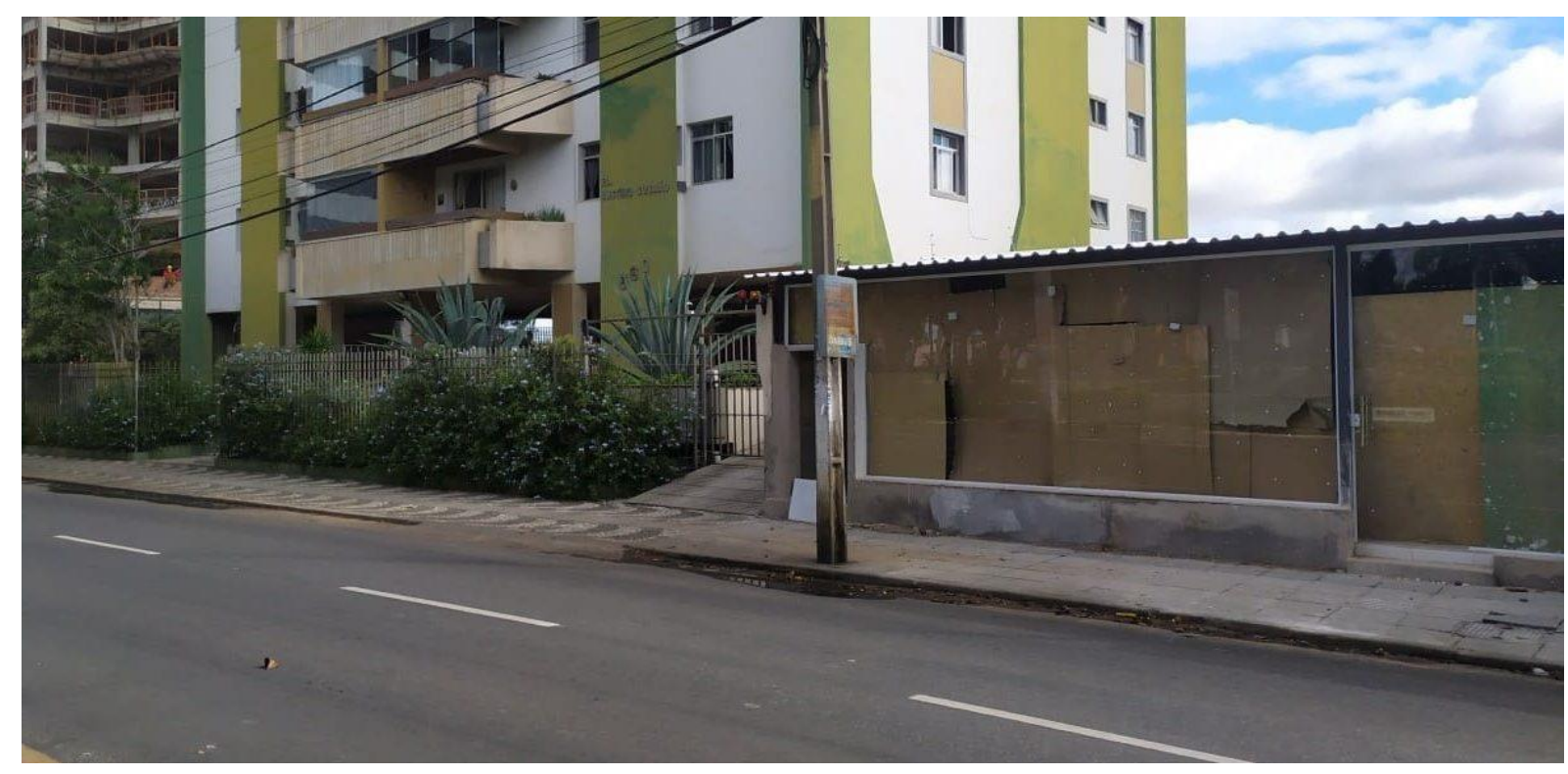

Fonte: Elaborada pelos autores

Nesse trecho, ainda, foram encontrados pontos de paradas identificados somente pela convenção dos usuários, já que não existe abrigo e nenhum tipo de indicação/sinalização. Neste trecho analisado, existem mais de 5 pontos estabelecidos por essa convenção. A Figura 20 apresenta um exemplo de um desses pontos, cuja sinalização é inexistente e a calçada apresenta inconformidades alarmantes com vegetação crescente, além de estar localizado exatamente na esquina do quarteirão. 


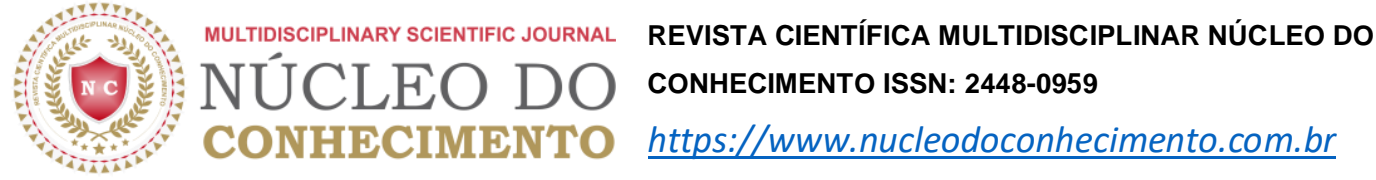

Figura 20 - Ponto sem sinalização

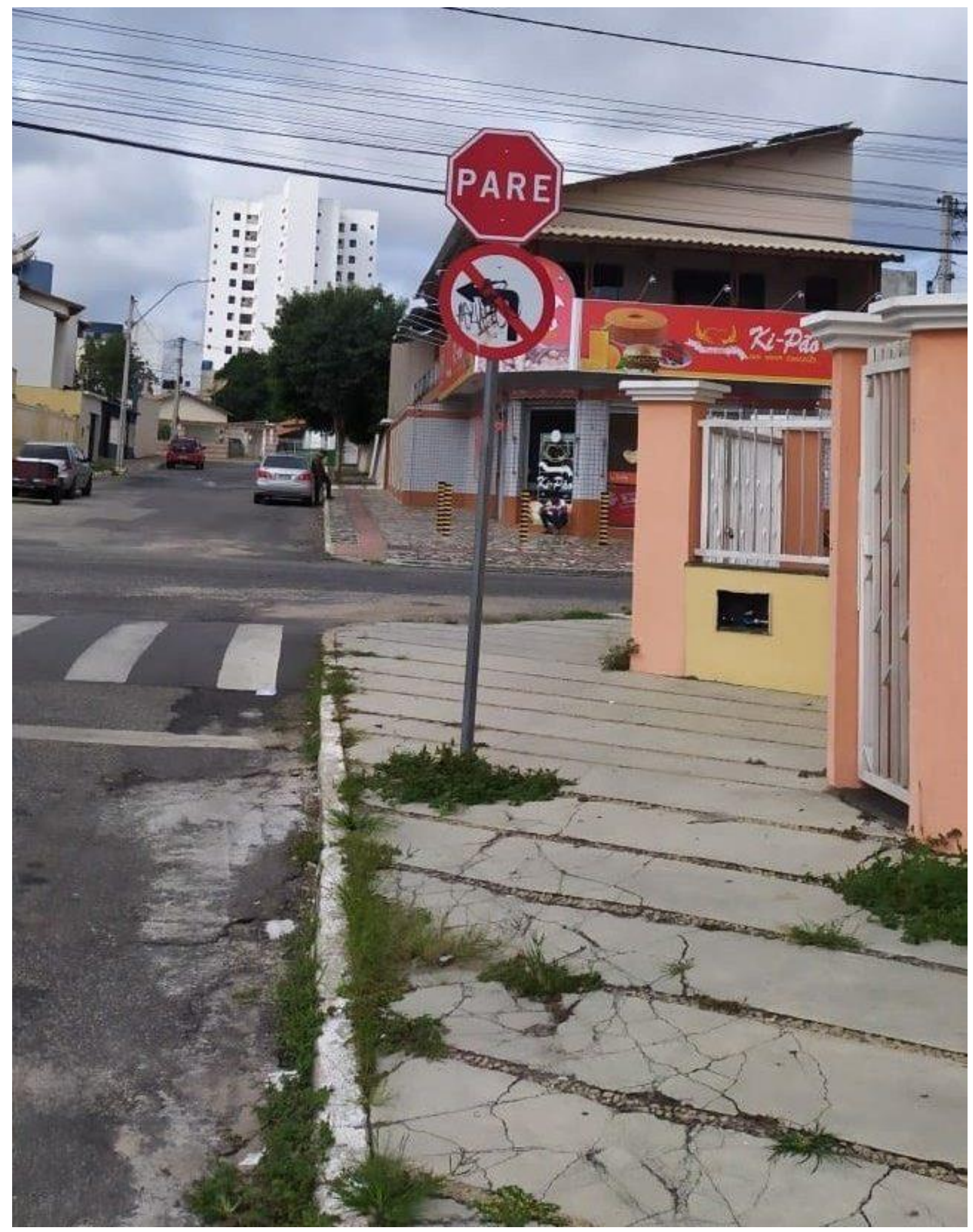

Fonte: Elaborada pelos autores

RC: 50831

Disponível em: https://www.nucleodoconhecimento.com.br/engenharia-civil/transporte-coletivo 
Como foi dito anteriormente, um dos critérios para escolha dessa linha de ônibus foi à existência de clínicas especializadas e associações de integração de pessoas com mobilidade reduzida e/ou portadoras de deficiência em seu trajeto, tais como a ACIDE, entretanto, o ponto de ônibus próximo a essa associação, indicado na Figura 21, não contempla os requisitos básicos da norma de acessibilidade. Contém somente a sinalização através da placa indicativa de ponto de parada, fixada também no poste de iluminação, e o piso tátil na extensão da calçada, contanto com um rebaixamento na calçada, mas em péssimas condições de preservação impossibilitando a sua utilização.

Figura 21 - Ponto próximo a associação de integração

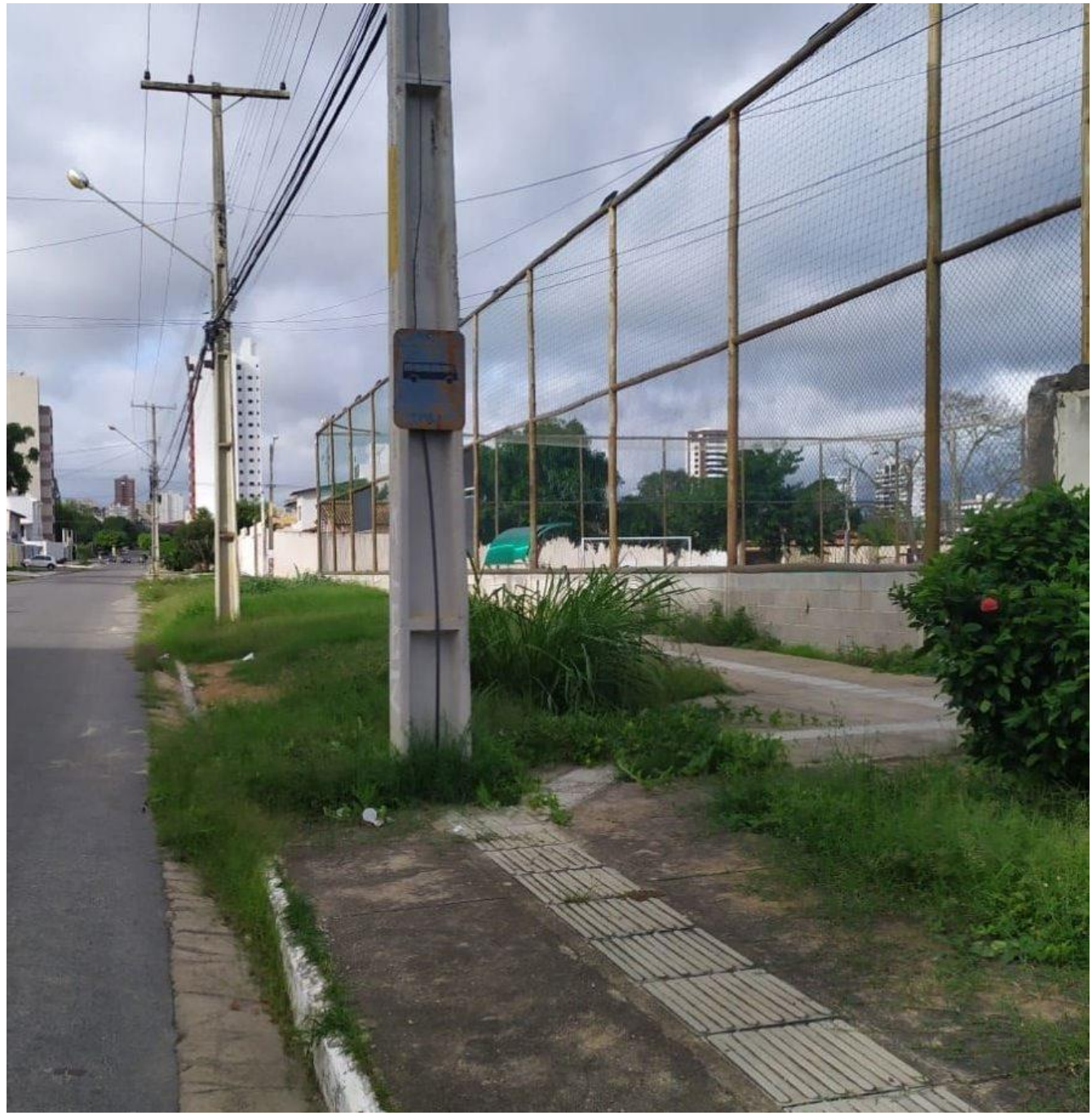

Fonte: Elaborada pelos autores 
O ponto de parada mais crítico encontrado foi o situado nas mediações do parque de exposições do município, mostrado na Figura 22. Como é possível perceber, o ponto não conta com nenhum tipo de abrigo, assento ou cobertura, a calçada está em péssimas condições, o que faz com que o descolamento de pessoas com algum tipo de deficiência e/ou mobilidade reduzida seja de uma dificuldade altíssima. Não existe rebaixamento da calçada em nenhum local da extensão desse quarteirão. O que torna a condição desse ponto ainda mais agravante é que, por estar situado no meio do trecho da linha, ele possui um nível considerável de usuários embarcando e desembarcando, e com essas condições a espera pelo ônibus se torna bastante desconfortável.

Figura 22 - Ponto sem sinalização e péssimas condições

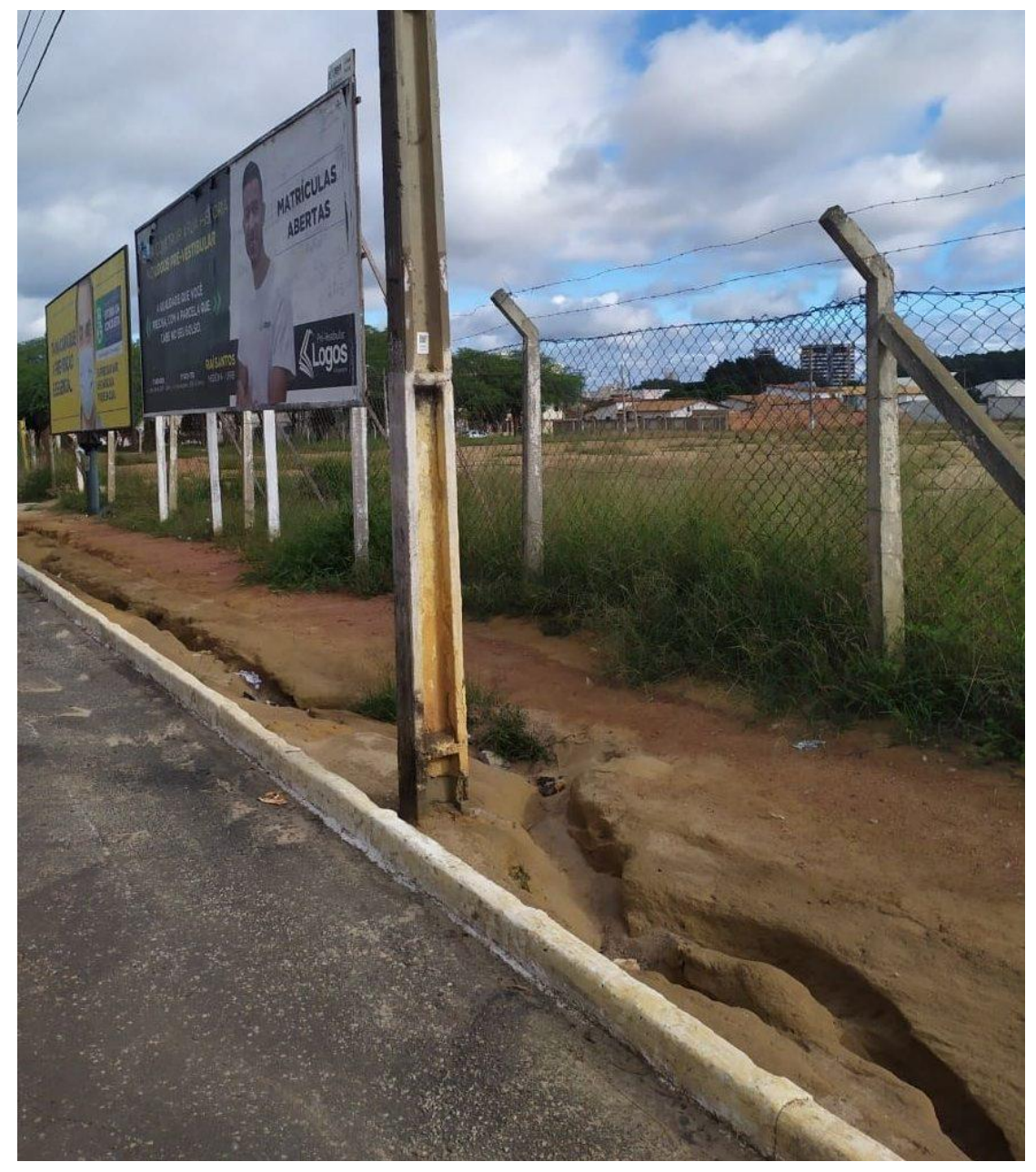

Fonte: Elaborada pelos autores 
Poucos foram os pontos do trecho analisado que contemplavam todas as exigências contidas em normas e leis. Em comparação à quantidade total de pontos de parada existente, a quantidade de pontos que contavam com sinalização correta, rebaixamento da via, piso tátil, etc, se torna irrisória, podendo apresentar assim uma visão a respeito da atual situação do sistema de transporte por ônibus no município.

\section{CONSIDERAÇÕES FINAIS}

Conforme foi visto, existe um número considerável de normas e legislações vigentes que tratam dos assuntos acessibilidade e mobilidade urbana, e ainda assim a situação do sistema de transporte coletivo, assim como das cidades como um todo, deixa a desejar.

Visto isso, é imprescindível que o planejamento das cidades seja feito levando em consideração aspectos como a acessibilidade como primordiais para que o desenvolvimento das mesmas seja ordenado e eficiente.

No trecho analisado, por meio da análise dos dados coletados, foi possível observar de forma bastante evidente as limitações existentes do sistema de transporte coletivo do município de Vitória da Conquista, em relação à acessibilidade dos pontos de parada. Observou-se, de maneira geral, que a linha analisada, mesmo contando com um alto número de usuários portadores de deficiência e/ou mobilidade reduzida, não está apta para recebê-los, pois são poucos os pontos de embarque e desembarque que seguem a risca todas as normativas e leis.

Através dos dados explanados neste trabalho, é possível ter uma noção a respeito das condições do sistema de transporte coletivo, ao passo que o número de pontos que seguem a risca as normas de acessibilidade é nulo, tendo somente poucos pontos que se aproximam desse padrão, e no geral os pontos de embarque e desembarque existentes não contam com nada além da sinalização, ou em alguns casos, nem isso.

Essa pesquisa traz, mesmo que através da investigação de um único trecho de uma linha, noções sobre as condições do TCU do município, no que se refere à condição 
dos veículos, itinerário, rota, esses não foram tópicos especificamente abordados, mas foi possível de serem analisadas e vistas às condições precárias que se encontram. Com isso, conclui-se que é necessário urgente intervenção do governo municipal no sistema de TCU como um todo. Espera-se que após a reforma da Estação de Transbordo o município concentre suas ações na readequação dos pontos de parada, para que não se tenha somente um terminal de ônibus revitalizado e bonito, mas sim um sistema de transporte eficiente.

\section{REFERÊNCIAS}

ASSOCIAÇÃO BRASILEIRA DE NORMAS TÉCNICAS. NBR 14022: Acessibilidade em veículos de características urbanas para o transporte coletivo de passageiros. Rio de Janeiro, 2011.

ASSOCIAÇÃO BRASILEIRA DE NORMAS TÉCNICAS. NBR 15570: Transporte Especificações técnicas para fabricação de veículos de características urbanas para transporte coletivo de passageiros. Rio de Janeiro, 2009.

ASSOCIAÇÃO BRASILEIRA DE NORMAS TÉCNICAS. NBR 15599: Acessibilidade Comunicação na prestação de serviços. Rio de Janeiro, 2016.

ASSOCIAÇÃO BRASILEIRA DE NORMAS TÉCNICAS. NBR 15646-1: Acessibilidade - Plataforma elevatória veicular e rampa de acesso veicular para acessibilidade em veículos com características urbanas para o transporte coletivo de passageiros. Rio de Janeiro, 2016.

ASSOCIAÇÃO BRASILEIRA DE NORMAS TÉCNICAS. NBR 15646-2: Plataforma elevatória veicular e rampa de acesso veicular para acessibilidade em veículos com características urbanas para o transporte coletivo de passageiros - Requisitos de desempenho, projeto, instalação e manutenção. Rio de Janeiro, 2016.

ASSOCIAÇÃO BRASILEIRA DE NORMAS TÉCNICAS. NBR 16537: Acessibilidade Sinalização tátil no piso - Diretrizes para elaboração de projetos e instalação. Rio de Janeiro, 2016. 
ASSOCIAÇÃO BRASILEIRA DE NORMAS TÉCNICAS. NBR 9050: Acessibilidade de pessoas portadoras de deficiências a edificações, espaço, mobiliário e equipamentos urbanos. Rio de Janeiro, 2015.

ASSOCIAÇÃO BRASILEIRA DE NORMAS TÉCNICAS. NBR ISO 9386-1: Plataforma de elevações motorizadas para pessoas com mobilidade reduzida - requisitos para seguranças. Dimensões e operação funcional. Rio de Janeiro, 2013.

BALASSIANO, Ronaldo. Transporte por vans: 0 que considerar no processo de regulamentação? Transportes, v. 4, n. 1, 1996.

BRASIL. Lei no 12.587, de 3 de janeiro de 2012. Institui as diretrizes da Política Nacional de Mobilidade Urbana, Brasília, 2015. Disponível em: <http://www.planalto.gov.br/ccivil_03/_ato2011-2014/2012/lei//12587.htm>. Acesso em: jan. 2020.

BRASIL. Lei no 7853, 24 de outubro de 1989. Dispõe sobre a Política Nacional para a Integração da Pessoa Portadora de Deficiência. Brasília, 1989. Disponível em: <http://www.planalto.gov.br/ccivil_03/leis//7853.htm>. Acesso em: jan. 2020.

BRASIL. Lei no. 10.098, de 19 de Dezembro de 2000. Estabelece normas gerais e critérios básicos para a promoção da acessibilidade das pessoas portadoras de deficiência ou com mobilidade reduzida, e dá outras providências. Diário Oficial [da República Federativa do Brasil], Brasília. Disponível em: <https://www.presidencia.gov.br/ccvivil_03/Leis/L10098.htm> . Acesso em:dez. 2019.

BRUMER, Anita; PAVEI, Katiuci; MOCELIN, Daniel Gustavo. Saindo da escuridão: perspectivas da inclusão social, econômica, cultural e política dos portadores de deficiência visual em Porto Alegre. Sociologias. Porto Alegre. Vol. 6, n. 11 (jan./jun. 2004), p. 300-327, 2004.

CAMARGO, Eder Pires de. Inclusão social, educação inclusiva e educação especial: enlaces e desenlaces. Ciência \& Educação (Bauru), v. 23, n. 1, p. 1-6, 2017. 
CAMPOS, Vânia Barcellos Gouvêa. Planejamento de transportes: conceitos e modelos. Rio de Janeiro: Interciência, v. 174, 2013. Capítulo 1.

DA SILVA, André Luiz Bezerra. Circulação, transporte e espaço urbano. Revista de Geografia - PPGEO-UFJF, v. 1, n. 2, 2011.

DE ARAUJO SILVA, Daniel; LOBODA, Carlos Roberto. Circulação urbana: um estudo sobre a mobilidade em Ituiutaba, MG. Revista NUPEM, v. 9, n. 16, p. 54-70, 2017.

DE ARAÚJO, Marley Rosana Melo et al. Transporte público coletivo: discutindo acessibilidade, mobilidade e qualidade de vida. Psicologia \& Sociedade, v. 23, n. 3, p. 574-582, 2011.

DE VASCONCELLOS, Eduardo Alcântara; DE CARVALHO, Carlos Henrique Ribeiro; PEREIRA, Rafael Henrique Moraes. Transporte e mobilidade urbana. Texto para Discussão, Instituto de Pesquisa Econômica Aplicada (IPEA), 2011.

Dicionário Michaelis. Disponível em:<http://michaelis.uol.com.br/modernoportugues/>. Acesso em nov. 2019.

DUARTE, Fábio; LIBARDI, Rafaela. Introdução à mobilidade urbana. Jurua Editora, 2017.

FEDERAL, Senado. Constituição federal de 1988. Fonte: Planalto. gov. br: http://www. planalto. gov. br/ccivil_03/constituicao/constituicaocompilado. htm, 1988. Acesso em nov. 2019.

FERRAZ, Antonio Clovis Pinto; TORRES, Isaac Guillermo Espinosa. Transporte público urbano. RiMa Editora, 2001.

Global designing cities initiative; national association of city transportation officials. Global Street design guide. Island Press, 2016. 
GROTTA, Carlos Alberto Diniz. O transporte urbano e a circulação na abordagem espacial: análise do transporte coletivo urbano da região do $A B C D$, Grande São Paulo. 2005.

HERMONT, Liliana Delgado. Implantação de sistemas de transporte acessíveis. Ministério das Cidades, 2006.

IBGE - INSTITUTO BRASILEIRO DE GEOGRAFIA E ESTATÍSTICA. Cartilha Censo 2010. Disponível em:<www.pessoascomdeficiencia.gov.br>. Acesso em: 25 out. 2019.

KATO, Ricardo Bentes; BORDALO, Bernardo Macêdo; DA SILVA CAMELO, Tiago. Análise de percepção qualitativa do transporte público: um estudo de caso na cidade de Belém/PA. REEC-Revista Eletrônica de Engenharia Civil, v. 11, n. 2, 2016.

LANZONI, Cristine; SCARIOT, Cristiele; SPINILLO, Carla Galvão. Sistema de informação de transporte público coletivo no Brasil: algumas considerações sobre demanda de informação dos usuários em pontos de parada de ônibus. InfoDesign-Revista Brasileira de Design da Informação, v. 8, n. 1, p. 54-63, 2011.

LOMBARDO, ADILSON; CARDOSO, OLGA REGINA; SOBREIRA, PAULO EDUARDO. Mobilidade e Sistema de Transporte Coletivo. Revista Eletrônica OPET-Administração e Ciências Contábeis, n. 7, 2012.

MEDEIROS, Ruy H. A. - Notas Críticas ao livro "O Município da Vitória" de Tranquilino Torres, p.67.

MILARÉ, Édis. Política nacional de mobilidade urbana. Unisul de Fato e de Direito: revista jurídica da Universidade do Sul de Santa Catarina, v. 7, n. 12, p. 59-67, 2016.

MINISTÉRIO DAS CIDADES. Secretaria Nacional de Mobilidade Urbana. Caderno Técnico para Projetos de Mobilidade Urbana. Sistemas de Prioridade ao Ônibus. São Paulo, 2016.

MOOVIT. Cidades com Moovit. 2020. Acesso fev de 2020. https://moovitapp.com/ 
MURATA, Cintia Midori de Souza. Análise de acessibilidade dos pontos de parada do sistema de transporte coletivo por ônibus na cidade de Campo Mourão-PR, segundo a ABNT NBR 9050: 2004. 2015. Trabalho de Conclusão de Curso. Universidade Tecnológica Federal do Paraná.

ONU. Programa de Ação Mundial para as Pessoas Deficientes. Assembleia Geral da Organização das Nações Unidas. 1982.

RODRIGUES, Miriane dos Santos. SANTOS, Lethícia Anielly Oliveira. FONSECA, Luiz Felipe da Silva da. Acessibilidade urbana: Análise das condições de acesso à pessoa com deficiência e mobilidade reduzida em via pública no centro da Cidade de Gurupi-TO. Revista Científica Multidisciplinar Núcleo do Conhecimento. Ano 05, Ed. 03, Vol. 09, pp. 81-101. Março de 2020. ISSN: 2448-0959.

SILVA, Marília do Nascimento; LAPA, Tomás de Albuquerque. 0 transporte público coletivo sob a lógica da produção capitalista do espaço: uma análise do serviço de ônibus na Região Metropolitana do Recife. Cadernos Metrópole, v. 21, n. 45, p. 511-530, 2019.

SILVEIRA, Márcio Rogério; RODRIGO, Giraldi Cocco. Transporte público, mobilidade e planejamento urbano: contradições essenciais. 2013.

VASCONCELLOS, E. A. Transporte urbano, espaço e equidade. São Paulo: FAPESP, 1996. Vitória da Conquista (BA). Prefeitura. 2014. Disponível em: $<$ http://www.pmvc.ba.gov.br>. Acesso em: out. 2019.

VITÓRIA DA CONQUISTA. Lei no 520, de 05 de Abril de 1990. Autoriza reserva de lugares em transportes coletivos a pessoas indicadas, Vitória da Conquista - BA, 1990. Disponível em: $<$ https://www.pmvc.ba.gov.br/wpcontent/uploads/Lei_520_90_RESERVA-DE-LUGARES-EM-TRANSPORTESCOLETIVOS.pdf>. Acesso em: jan. 2020.

VITÓRIA DA CONQUISTA. Lei no 802, de 27 de Outubro de 1994. Dispõe sobre o horário de atendimento ao usuário do transporte coletivo urbano, Vitória da Conquista 
- BA, 1994. Disponível em: <https://www.pmvc.ba.gov.br/wpcontent/uploads/Lei_802_94_HORARIO-DE-ATENDIMENTO-AO-USUARIO-DOTRANSPORTE-COLETIVO-URBANO.pdf>. Acesso em: jan. 2020.

VITÓRIA DA CONQUISTA. Lei no 968, de 07 de Maio de 1999. Dispõe sobre o sistema municipal de transporte público e regulamenta a prestação do serviço de transporte coletivo, Vitória da Conquista - BA, 1999. Disponível em: $<$ <ttps://www.pmvc.ba.gov.br/wp-content/uploads/Lei_968_99_SISTEMAMUNICIPAL-DE-TRANSPORTE-PUBLICO-E-REGULAMENTA-A-PRESTACAO-DOSERVICO-DE-TRANSPORTE-COLETIVO.pdf>. Acesso em: jan. 2020.

Enviado: Maio, 2020.

Aprovado: Maio, 2020. 